Fabian Thomas, Dominik Steden, Alexander Eith, Alexander Hoffmann and Sonja Herres-Pawlis*

\title{
Chiral bis(pyrazolyl)methane copper(l) complexes and their application in nitrene transfer reactions
}

https://doi.org/10.1515/znb-2021-0140

Received September 14, 2021; accepted October 7, 2021; published online October 29, 2021

\begin{abstract}
In this study, chiral bis(pyrazolyl)methane copper(I) acetonitrile complexes were applied to generate two novel terminal copper tosyl nitrene complexes with the nitrene generating agent ${ }^{\mathrm{S}} \mathrm{PhINTs}$ in dichloromethane at low temperatures. The syntheses of the chiral bis(pyrazolyl) methane ligands are based on pulegone and camphor, members of the natural chiral pool. The chiral copper(I) acetonitrile complexes were applied as catalysts in the copper nitrene mediated aziridination reaction of different styrene derivatives and the $\mathrm{C}-\mathrm{H}$ amination of various substrates. The reactions afforded good yields, but low enantiomeric excess under mild conditions. The nitrene species have been characterized with UV/Vis and EPR spectroscopy and the products of the decay by ESI mass spectrometry.
\end{abstract}

Keywords: asymmetric catalysis; aziridination; copper; $\mathrm{N}$-donor ligands; terminal nitrenes.

Dedicated to: Professor Richard Dronskowski of the RWTH Aachen on the occasion of his 60th birthday.

\section{Introduction}

Nitrogen-containing motifs are found in a variety of synthetically [1], biologically [2] and pharmaceutically [3]

\footnotetext{
*Corresponding author: Sonja Herres-Pawlis, Institute of Inorganic Chemistry, RWTH Aachen University, Landoltweg 1a, 52074 Aachen, Germany, E-mail: sonja.herres-pawlis@ac.rwth-aachen.de. https:// orcid.org/0000-0002-4354-4353

Fabian Thomas, Dominik Steden, Alexander Eith and Alexander Hoffmann, Institute of Inorganic Chemistry, RWTH Aachen University, Landoltweg 1a, 52074 Aachen, Germany,

E-mail: fabian.thomas@ac.rwth-aachen.de (F. Thomas), dominik.steden@ac.rwth-aachen.de (D. Steden), alexander.eith@rwth-aachen.de (A. Eith), alexander.hoffmann@ac.rwth-aachen.de (A. Hoffmann). https:// orcid.org/0000-0003-4941-3175 (F. Thomas). https://orcid.org/ 0000-0002-8346-7751 (D. Steden). https://orcid.org/0000-0002 9647-8839 (A. Hoffmann)
}

relevant molecules. In biologically and pharmacologically active molecules, asymmetric amines are of high interest [4, 5]. Nitrogen-containing motifs are achieved by direct functionalization of unreactive $\mathrm{C}-\mathrm{H}$ bonds with high atom effciency [6-9]. This can be approached synthetically by inserting a metal-bound nitrene into a $\mathrm{C}-\mathrm{H}$ bond $[10,11]$ and a variety of suitable metals and ligands can be used [12-16]. Due to their low cost, low toxicity and good environmental compatibility copper complexes were studied extensively. Reaction protocols for catalytic $\mathrm{C}-\mathrm{H}$ aminations [17-24], N-group transfer [17, 25-38] and asymmetric aziridination [39-45] were developed, while also asymmetric cobaltcatalyzed $\mathrm{C}-\mathrm{H}$ amination reactions [46] were developed. For these copper-catalyzed reactions the key intermediates have been proposed to be copper nitrene complexes based on experimental $[43,47]$ and theoretical $[17,23,37,48-52]$ investigations.

Essential for the reactivity is the presence of terminal copper nitrene complexes, which mediate the reactivity $[17,18,23,37,38,43,47-54]$. In the literature only a limited number of stable copper nitrene complexes are presented (Figure 1). Pioneer work on copper nitrene complexes was carried out by the Warren group, who reported the molecular structure of different $\mu$-nitrene-bridged dicopper complexes stabilized by anionic NacNac ligands. Catalytic reactivity is observed due to the dissociation of the dimetallic complex into a terminal copper nitrene complex $[47,55,56]$. The catalytic reactivity of this system was further investigated and various nitrene generating agents and substrates were successfully applied [24, 57]. The Ray group reported stable copper nitrene complexes coordinated by neutral amine ligands. These can be stabilized by incorporation into an azamacrocycle [58] or by the addition of scandium(III) triflate $[59,60]$. While the latter copper nitrene complex can be generated from azides and iminoiodinane, the iminoiodinane nitrene complexes tend to give a tautomeric copper imidyl form [61]. The Bertrand group presented stable copper nitrenes synthesized from a metal free phosphonitrene. The phosphonitrene can coordinate in different stoichiometries and forms a $\mu$-nitrene-bridged, a terminal nitrene and a twofold coordinated species [62]. In contrast to those singlet copper nitrene complexes, the Betley group reported a terminal copper nitrene complex in the triplet state stabilized by 


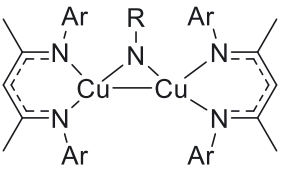

Warren 2006-2013

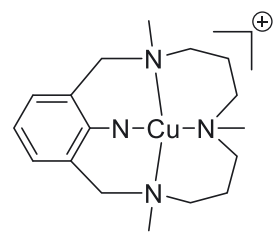

Company, Ray, Ribas 2016

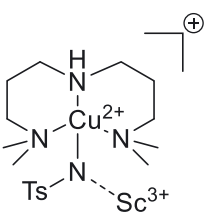

Ray, 2012-2014

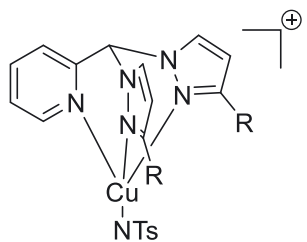

Herres-Pawlis 2018-2021

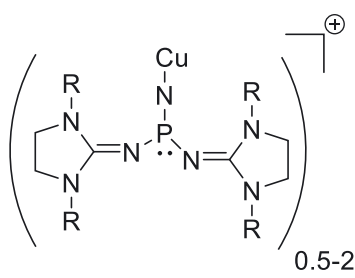

Bertrand 2014<smiles></smiles>

Betley, 2019
Figure 1: Literature-known [24, 47, 55-65] stable copper nitrene complexes. a sterically demanding dipyrrol ligand. The complex was characterized using XAS and NMR spectroscopy and multireference calculations of a truncated system. Furthermore, it was shown that the nitrene complex is capable of mediating catalytic aziridination and $\mathrm{C}-\mathrm{H}$ amination reactions [63]. In previous work, our group presented a series of terminal singlet bis(pyrazolyl)methane copper nitrene complexes. These nitrene complexes were stabilized and characterized at low temperature. It was shown that the ligand design of the used bis(pyrazolyl)-methane ligands is crucial for the stability and the reactivity of the copper nitrene complexes. Additionally, protocols for aziridination reactions and $\mathrm{C}-\mathrm{H}$ amination of different substrate classes under mild conditions were developed. Furthermore, the mechanism of the aziridination was studied theoretically and experimentally. It could be shown that the aziridination of styrene mainly follows a singlet pathway [64, 65].

Herein, heteroscorpionate ligands of the bis(pyrazolyl)methane family were used. This ligand family was chosen because it was shown in the past that these ligands can be tailor-made for a variety of applications [66]. This includes a tyrosinase-like catalytic phenol hydroxylation [67-70], the oxidation of benzylalcohols with modified microgels [71], a palladium-free Sonogashira cross coupling $[72,73]$ and the asymmetric cyclopropanation of styrene [74-76].

\section{Results and discussion}

\subsection{Synthesis and characterization of ligands and copper complexes}

Three novel bis(pyrazolyl)methane ligands were synthesized. Two of the ligands are based on molecules of the chiral pool,

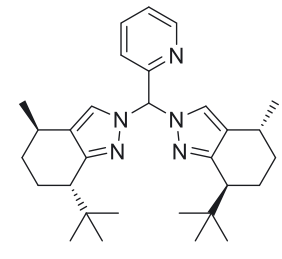

L1

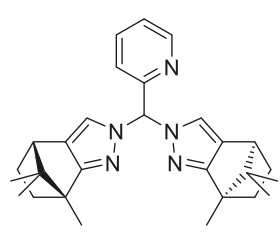

L2

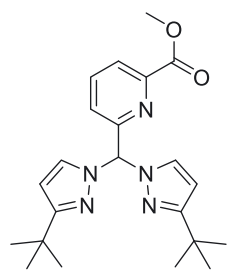

L3
Figure 2: Novel bis(pyrazolyl)methane ligands.

namely on a modified pulegone moiety $\left(\mathrm{HC}(\mathrm{PulPz})_{2} \mathrm{Py}, \mathbf{L 1}\right)$ or on a camphor moiety $\left(\mathrm{HC}(\mathrm{CamPz})_{2} \mathrm{Py}, \mathbf{L 2}\right)$. In contrast, the third ligand has sterically demanding groups on the pyridine group and on the pyrazolyl units $\left(\mathrm{HC}\left({ }^{t} \mathrm{BuPz}\right)_{2}\left(6-\mathrm{CO}_{2} \mathrm{MePy}\right)\right.$, L3, Figure 2) but no chiral information.

The ligands $\mathbf{L} \mathbf{1}$ and $\mathbf{L} \mathbf{2}$ were synthesized to study the influence of the steric demand of different pyrazolyl units whereas in $\mathbf{L} \mathbf{3}$ the influence of a sterically demanding pyrazolyl unit and a substituted pyridine unit were evaluated. All three bis(pyrazolyl)methane ligands were synthesized by a modified Peterson rearrangement [77]. Therefore, the used pyrazole was deprotonated by sodium hydride in THF. In the next step thionyl chloride was added to form a bis(pyrazolyl)sulfonyl species. This species is rearranged by cobalt(II) chloride and an aldehyde to the ligand. For the ligands $\mathbf{L 1}$ (73\%) and $\mathbf{L 3}$ (59\%) high yields were obtained, while for $\mathbf{L} 2$ only a yield of $26 \%$ was observed. By adding $\left[\mathrm{Cu}(\mathrm{MeCN})_{4}\right] \mathrm{PF}_{6}$ to the ligand solution, the copper(I) acetonitrile complexes were obtained and isolated for all three ligands (C1: $[\mathrm{CuL1}$ (MeCN)]PF, C2: [CuL2(MeCN)]PF 6 , C3: [CuL3(MeCN)]PF , Figure 3). The complex $\mathbf{C 2}$ is not stable in pure acetonitrile or in acetonitrile-free solution, whereas the formation of the dinuclear complex $\mathbf{C 4}\left(\left[\mathrm{Cu}_{2} \mathbf{L 2}_{2}\right]\left(\mathrm{PF}_{6}\right)_{2}\right.$, Figure 3$)$ is observable thanks to a color change from pale yellow to intense yellow. 


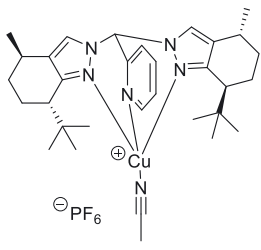

C1

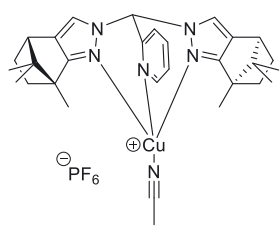

C2

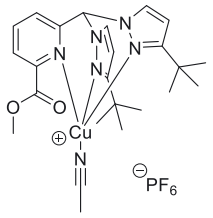

C3

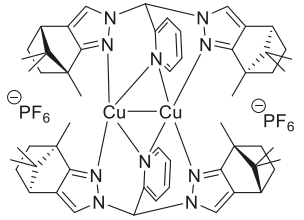

C4
Figure 3: Novel copper(I) bis(pyrazolyl)methane complexes.
The instability of $\mathbf{C} 2$ in solution also limited the scale of the synthesis of $\mathbf{C 2}$. The equilibrium of both complexes in a solution can be pushed to $\mathbf{C} 2$ by the addition of 10 equivalents of acetonitrile in relation to C2. For further application, C2 was synthesized in situ from dissolved $\mathbf{C 4}$ by the addition of 20 equivalents of acetonitrile to a dichloromethane solution of C4. Starting from a solution of C4, the formation of $\mathbf{C} \mathbf{2}$ can also be observed by a change of the electrochemical properties (Table S1, Supplementary material available online; see the link given at the end of the paper) and the differences in the NMR spectra (Figure S8). For both complexes an irreversible one electron transfer is observed in the CV measurements. Furthermore, it is noticeable that the potential of C2 $(630 \mathrm{mV})$ is lower than for $\mathbf{C 4}(1230 \mathrm{mV})$. Of the four novel copper(I) complexes three could be analyzed with single crystal X-ray diffraction. The cations of the three complexes are shown in Figure 4 (ellipsoid plots: see Figure S6), key bond lengths and angles are presented in Table 1 and the crystallographic details are given in Table S6 (SI). In C3, four independent molecules are found in the asymmetric unit with equal (within the standard deviation) or very similar bond lengths and angles. Therefore, only the bond lengths and angles of one copper complex are given in Table 1 (for the other independent molecules: see Table S7). The torsion angle between the pyridine group and the carbonyl group varies between $-16.7(1)^{\circ}$ and $156.3(1)^{\circ}$ (see Table S7). In the three copper(I) complexes $\mathbf{C 1}, \mathbf{C} 3$ and $\mathbf{C 4}$, the copper ion is distorted tetrahedrally coordinated. In $\mathbf{C 1}$ and $\mathbf{C 3}$, the copper ion is coordinated by the two N-donor atoms of the pyrazoyl units, the $\mathrm{N}$-donor of the pyridine unit and the $\mathrm{N}$-donor of the coordinating acetonitrile molecule. The bond length of the pyridinyl N-donor in $\mathbf{C} 3$ is elongated in comparison to $\mathbf{C 1}$ due to the different electronic influence of the substituted pyridinyl unit [67]. In C4 each copper ion is coordinated by a pyridine and a pyrazolyl unit from one ligand and a pyrazolyl unit from the second ligand. The $\mathrm{N}$-donor of the pyridinyl unit acts as bridge between both copper ions.

The complex C1 can be compared with different bis(pyrazolyl)methane complexes with different substituted pyrazolyl units, for example with phenyl [65], tert-butyl [64] or $\mathrm{CF}_{3}$ [64] substituted pyrazolyl units. It is observed that the nature of the substitution of the pyrazolyl unit leads to slightly different pyrazolyl copper bond lengths, which are the same within the $3 \sigma$ error margin (C1: 2.046(4) $\AA$, 2.100(5) $\AA$, $\left.\left[\mathrm{Cu}(\mathrm{PhPz})_{2} \mathrm{Py}\right\} \mathrm{HC}(\mathrm{MeCN})\right] \mathrm{PF}_{6}: 2.066(3) \AA$ A, 2.067(3) $\AA$, $[\mathrm{Cu}$ $\left.\left\{\mathrm{HC}\left({ }^{t} \mathrm{BuPz}\right)_{2} \mathrm{Py}\right\} \mathrm{HC}(\mathrm{MeCN})\right] \mathrm{PF}_{6}: 2.056(2) \AA$, 2.107(2) $\AA$, [Cu $\left.\left\{\mathrm{HC}\left(\mathrm{CF}_{3} \mathrm{Pz}\right)_{2} \mathrm{Py}\right\}(\mathrm{MeCN})\right]\left\{\mathrm{HCPF}_{6}: 2.089(6) \AA\right.$, 2.093(5) $\AA$ ).

Complex $\mathbf{C} 3$ can be compared to the literature known complex $\left[\mathrm{Cu}\left\{\mathrm{HC}\left({ }^{t} \mathrm{BuPz}\right)_{2} \mathrm{Py}\right\}(\mathrm{MeCN})\right] \mathrm{PF}_{6}$ [64]. The copper pyridinyl bond length is elongated in $\mathbf{C} 3$ compared to the reference complex (2.088(3) Å), indicating that through the introduction of the methyl ester group the donor strength is lowered. This effect was also reported for the complex $\left[\mathrm{Cu}\left\{\mathrm{HC}\left({ }^{t} \mathrm{BuPz}\right)_{2}\left(4-\mathrm{CO}_{2} \mathrm{MePy}\right)\right\} \mathrm{Br}\right]$ [67], were the methyl ester group is in a different position on the pyridinyl ring. A comparison between this complex (2.153(3) $\AA$ ) and C3 is difficult, due to the coordinating bromido anion.

When the dinuclear complex $\mathbf{C 4}$ is compared to the dinuclear complex $\left[\mathrm{Cu}_{2}\left\{\mathrm{HC}\left(\mathrm{Ph}_{2} \mathrm{Pz}\right)_{2} \mathrm{MeIm}\right\}_{2}\right]\left(\mathrm{PF}_{6}\right)_{2}[65]$ it is observed that the $\mathrm{Cu}-\mathrm{Cu}$ bond length (2.568(1) $\AA$ : C4:

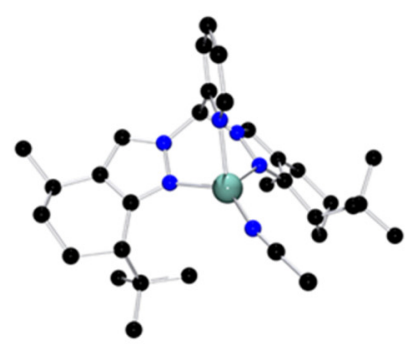

C1

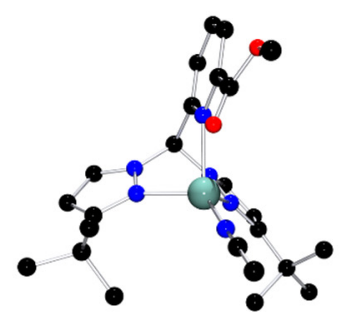

C3

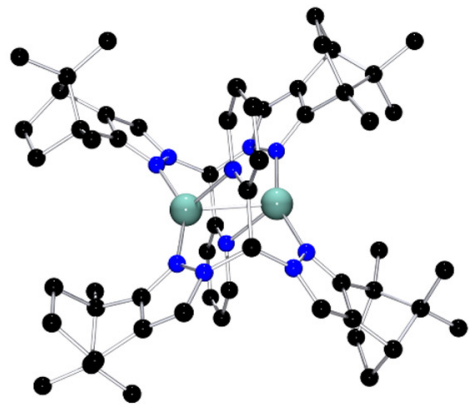

C4

Figure 4: Molecular structures of the complex cations of $\mathrm{C} 1$ in crystals of $\left[\mathrm{Cu}\left\{\mathrm{HC}(\mathrm{PulPz})_{2} \mathrm{Py}\right\}(\mathrm{MeCN})\right] \mathrm{PF}_{6}, \mathrm{C} 3$ in crystals of $\left[\mathrm{Cu}\left\{\mathrm{HC}\left({ }^{\mathrm{t} B u P z}\right)_{2}\left(\mathrm{CO}_{2} \mathrm{MePy}\right)\right\}(\mathrm{MeCN})\right] \mathrm{PF}_{6} \cdot \mathrm{CH}_{2} \mathrm{Cl}_{2}$ and $\mathrm{C} 4$ in crystals of $\left[\mathrm{Cu}\left\{\mathrm{HC}(\mathrm{CamPz})_{2} \mathrm{Py}\right\}_{2}\right]\left(\mathrm{PF}_{6}\right)_{2} \cdot 2 \mathrm{C}_{5} \mathrm{H}_{12} \cdot \mathrm{C}:$ black, $\mathrm{N}$ : blue, 0 : red, Cu: turquoise. $\mathrm{H}$ atoms, solvent molecules and anions are omitted for clarity. 
Table 1: Selected bond lengths and angles of the $\mathrm{Cu}(\mathrm{I})$ complexes.

\begin{tabular}{|c|c|c|c|}
\hline & C1 & C3 & C4 \\
\hline $\mathrm{Cu}-\mathrm{NCMe}(\AA ̊)$ & $1.872(5)$ & $1.905(7)$ & - \\
\hline $\mathrm{Cu}-\mathrm{N}\left(\mathrm{Pz}, \mathrm{Pz} \mathrm{z}^{\prime}\right)(\AA)$ & $\begin{array}{r}2.046(4) \\
2.100(5)\end{array}$ & $\begin{array}{r}2.055(6) \\
2.103(6)\end{array}$ & $\begin{array}{r}1.913(2), \\
1918(2)\end{array}$ \\
\hline $\mathrm{Cu}^{\prime}-\mathrm{N}\left(\mathrm{Pz}^{\prime \prime}, \mathrm{Pz}^{\prime \prime \prime}\right)(\AA)$ & - & - & $\begin{array}{r}1.918(2), \\
1.913(2)\end{array}$ \\
\hline $\mathrm{Cu}-\mathrm{N}\left(\mathrm{Py}, \mathrm{Py} \mathrm{y}^{\prime}\right)(\AA)$ & $2.120(5)$ & $2.194(6)$ & $\begin{array}{r}2.194(3) \\
2.336(3)\end{array}$ \\
\hline$C u^{\prime}-N\left(P y, P y^{\prime}\right)(\AA)$ & - & - & $\begin{array}{r}2.264(3) \\
2.414(3)\end{array}$ \\
\hline $\mathrm{Cu}-\mathrm{Cu}^{\prime}(\AA)$ & - & - & $2.586(1)$ \\
\hline $\mathrm{Cu} \cdots \mathrm{O}$ & - & $3.072(1)$ & - \\
\hline $\begin{array}{l}\mathrm{Cu}^{\prime} / \mathrm{MeCN}-\mathrm{Cu}- \\
\mathrm{N}\left(\mathrm{Pz}, \mathrm{Pz}^{\prime}\right)\left(^{\circ}\right)\end{array}$ & $\begin{array}{r}125.2(2), \\
136.6(2)\end{array}$ & $\begin{array}{r}125.8(1), \\
125.1(1)\end{array}$ & $\begin{array}{r}\text { 104.6(1), } \\
99.8(1)\end{array}$ \\
\hline $\begin{array}{l}\mathrm{Cu}^{\prime} / \mathrm{MeCN}-\mathrm{Cu}- \\
\mathrm{N}(\mathrm{Py})\left(^{\circ}\right)\end{array}$ & $115.4(2)$ & $126.4(1)$ & $\begin{array}{r}51.9(1) \\
57.1(1)\end{array}$ \\
\hline $\begin{array}{l}\mathrm{N}\left(\mathrm{Pz}, \mathrm{Pz}^{\prime}\right)-\mathrm{Cu}- \\
\mathrm{N}(\mathrm{Py})\left(^{\circ}\right)\end{array}$ & $\begin{array}{l}\text { 89.1(2), } \\
89.3(2)\end{array}$ & $\begin{array}{r}86.8(1) \\
91.2(1)\end{array}$ & - \\
\hline$\tau_{4}{ }^{a}$ & 0.70 & 0.76 & 0.68 \\
\hline
\end{tabular}

2.586(1) $\AA$ ) lies in the same range and the distortion of the tetrahedral coordination geometry (0.69) does not vary significantly, while there is a difference in the coordination of the two ligands to the copper ions. Both copper ions in $\left[\mathrm{Cu}_{2}\left\{\mathrm{HC}\left(\mathrm{Ph}_{2} \mathrm{Pz}\right)_{2} \mathrm{MeIm}\right\}_{2}\right]\left(\mathrm{PF}_{6}\right)_{2}$ are coordinated by the methyl imidazolyl unit from one ligand and both pyrazolyl units from the second ligand.

\subsection{Synthesis and characterization of the copper nitrene complexes}

Two novel chiral copper nitrene complexes were generated from the copper(I) acetonitrile complex and ${ }^{\mathrm{S}} \mathrm{PhINTs}$ (2-(tert-butyl-sulfonyl)( $p$-toluenesulfonyliminoiodo)benzene) in dichloromethane at low temperature. The reaction is shown in Figure 5 (top) on the example of C2. For both nitrene complexes a $k^{2}$-coordination of the nitrene fragment is assumed, due to observations with previously investigated bis(pyrazolyl)methane nitrene complexes [64, 65]. The reaction is indicated by a color change from colorless to an intense green and was monitored by UV/Vis spectroscopy. For C1 the formation of a nitrene complex $\left(\mathbf{N 1 P F}_{6}\right.$, [CuL1(NTs)]PF $)$ can be observed at $-80^{\circ} \mathrm{C}$. The formation of the nitrene complex ( $\mathbf{N 2 P F}_{6},[\mathrm{CuL} 2(\mathrm{NTs})] \mathrm{PF}_{6}$ ) from $\mathbf{C 2}$ needs higher temperature and a slow reaction between the copper(I) complex and ${ }^{S}$ PhINTs can be observed at $-63{ }^{\circ} \mathrm{C}$. In contrast, for the complexes $\mathbf{C} 3$ and $\mathbf{C 4}$ no formation of a stable nitrene complex could be observed. The nitrene formation starting from $\mathbf{C} 1$ and C2 is indicated in the UV/Vis spectra by two characteristic bands for terminal bis(pyrazolyl)methane copper nitrene complexes: one strong transition $\left(\varepsilon \approx 4000-7000 \mathrm{~L} \mathrm{~mol}^{-1} \mathrm{~cm}^{-1}\right)$ at about $410-420 \mathrm{~nm}$ and a weak transition $(\varepsilon \approx 500-$ $1000 \mathrm{~L} \mathrm{~mol}^{-1} \mathrm{~cm}^{-1}$ ) at about $620-650 \mathrm{~nm}$ (Figure 5, bottom) $[64,65]$.

The herein reported copper nitrene complexes have been characterized with previously established UV/Vis experiments for bis(pyrazolyl)methane copper nitrene

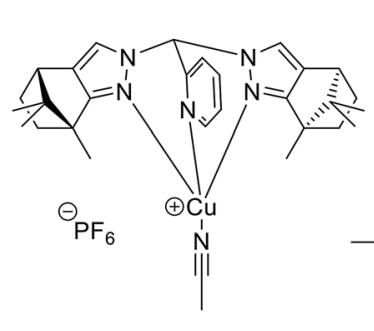

C2
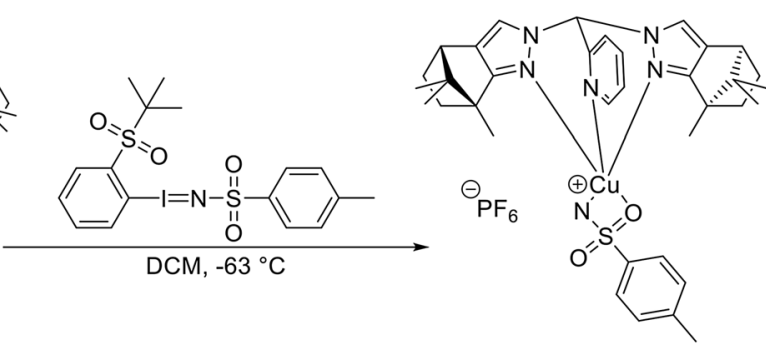

$\mathrm{N}_{2} \mathrm{PF}_{6}$

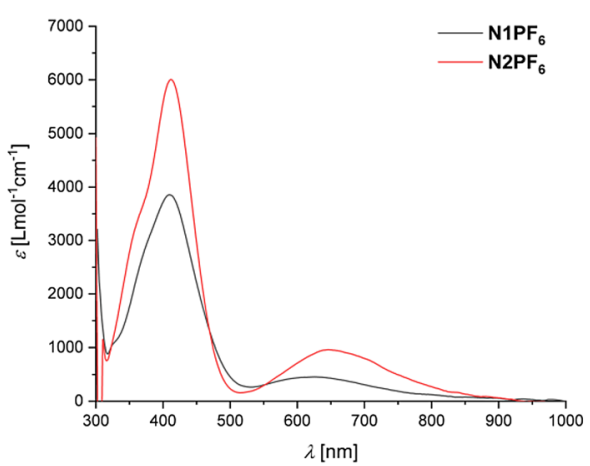

Figure 5: Top: reaction between [Cu $\left.\left\{\mathrm{HC}(\mathrm{CamPz})_{2} \mathrm{Py}\right\}(\mathrm{MeCN})\right] \mathrm{PF}_{6}(\mathrm{C} 2)$ and ${ }^{5} \mathrm{PhINTs}$ in dichloromethane for the synthesis of $\left[\mathrm{Cu}\left\{\mathrm{HC}(\mathrm{CamPz})_{2} \mathrm{Py}\right\}\left(\mathrm{NTs}_{\mathrm{N}}\right) \mathrm{PF}_{6}\right.$ $\left(\mathrm{N}_{2} \mathrm{PF}_{6}\right)$. Bottom: UV/Vis spectra of the two novel chiral copper nitrene complexes $\mathbf{N}^{1} \mathbf{P F}_{6}$ and $\mathbf{N} 2 \mathbf{P F}_{6}$ in DCM at low temperature. 
complexes $[64,65]$. This was achieved by a titration of ${ }^{\mathrm{S}}$ PhINTs against the copper(I) acetonitrile complex at low temperature (Figure S3). For the complex $\mathbf{C 1}$ the maximum in absorption was achieved after the addition of 1.0 equiv. of ${ }^{S}$ PhINTs, while for the complex $\mathbf{C 2}$ the absorption maximum was reached after the addition of 0.8 equivalent. This observation results from the slow reaction between ${ }^{S}$ PhINTs and $\mathbf{C 2}$ and the low stability of ${ }^{\mathrm{S}}$ PhINTs in solution. The formation of a nitrene from $\mathbf{C 2}$ has further been confirmed by the observation of $[\mathbf{N 2}-\mathrm{H}]^{+}$and $[\mathbf{N 2}+\mathrm{H}]^{+}$in the ESI mass spectrum of the decayed species (Figure S7 [SI]) while in the ESI mass spectrum of the decay products of $\mathbf{N 1 P F}_{6}$ only $[\mathrm{CuL1}]^{+}$was observed. The decay species can be the product of an intra or inter molecular $\mathrm{H}$ atom abstraction or addition [64]. The $\mathrm{H}$ atom addition is assumed on the nitrene nitrogen atom, while the abstraction can take place in the apical position or on the substituent of the pyrazolyl unit. The nitrene species $\mathbf{N} \mathbf{1} \mathbf{P F}_{\mathbf{6}}$ and $\mathbf{N} \mathbf{2} \mathbf{P F}_{\mathbf{6}}$ are terminal copper nitrenes complexes analogous to those presented in our previous publications $[64,65]$.

The thermal stability of both chiral copper nitrene complexes was investigated. The nitrenes were generated at $-80{ }^{\circ} \mathbf{C}$ for $\mathbf{N 1 P F}_{\mathbf{6}}$ or $-63{ }^{\circ} \mathrm{C}$ for $\mathbf{N 2}^{2} \mathbf{P F}_{\mathbf{6}}$ and the decay was observed at $-42{ }^{\circ} \mathrm{C}$ by UV/Vis spectroscopy. Both copper nitrene complexes decay to a species with a blue shifted absorption maximum (N1PF $\mathbf{6}$ by about $30 \mathrm{~nm}, \mathbf{N}_{\mathbf{2}} \mathbf{P F}_{\mathbf{6}}$ by about $50 \mathrm{~nm}$ ) but with a significantly lower extinction coefficient. The half-life time was determined as $2 \mathrm{~min}$ for $\mathbf{N 1}_{\mathbf{P}} \mathbf{F}_{\mathbf{6}}$ and $21 \mathrm{~min}$ for $\mathbf{N 2}_{\mathbf{P}} \mathbf{F}_{\mathbf{6}}$ (Table S2). For both nitrenes a decay with neither first nor second order was observed (Figure S4). This shows that the decay of the nitrene species is due to different reactions, as observed previously for bis(pyrazolyl)methane copper nitrene complexes [65]. Compared to other bis(pyrazolyl)methane copper nitrene complexes the stability of the two chiral nitrene complexes is low $[64,65]$. One reason for the low stability is that there are aliphatic hydrogen atoms in close contact to the nitrene moiety, which can be easily abstracted by the nitrene moiety. For example, the half-life time for the nitrene $[\mathrm{Cu}$ $\left.\left\{\mathrm{HC}\left({ }^{t} \mathrm{BuPz}\right)_{2} \mathrm{Py}\right\}(\mathrm{NTs})\right]^{+}$is $38 \mathrm{~min}$ while for the nitrene $[\mathrm{Cu}$ $\left.\left\{\mathrm{HC}(\mathrm{PhPz})_{2} \mathrm{Py}\right\}(\mathrm{NTs})\right]^{+}$a half-life time of $50 \mathrm{~min}$ is observed. Due to the nature of the ligands, the bond dissociation energy of $\mathrm{C}-\mathrm{H}$ bonds of the tert-butyl group in $\mathbf{N 1 P F}_{\mathbf{6}}$ is smaller compared to that of the $\mathrm{C}-\mathrm{H}$ bonds of the methyl group in $\mathbf{N} 2 \mathbf{P F}_{\mathbf{6}}$ leading to a lower half-life time.

In the next step, the yield of the nitrene generation was determined. One way to estimate the yield is by oxidizing ferrocene to ferrocenium. Ferrocenium has a characteristic $\mathrm{UV} / \mathrm{Vis}$ band at $624 \mathrm{~nm}$ with an extinction coefficient of $507 \mathrm{~L} \mathrm{~mol}^{-1} \mathrm{~cm}^{-1}$. The Lambert-Beer law allows to calculate the yield from the measured absorption [64, 65]. For the copper nitrene complexes $\mathbf{N 1 P F}_{\mathbf{6}}$ and $\mathbf{N}_{\mathbf{2}} \mathbf{P F}_{\mathbf{6}}$ a yield of $50 \%$ is obtained (Figure S5 and Table S3). In comparison to literature data $[64,65]$ for known bis(pyrazolyl)methane copper nitrene complexes $(Y=71-95 \%)$ the yield of the present nitrene complexes is lower. The low stability of $\mathbf{N 1 P F}_{\mathbf{6}}$ and the slow formation reaction of $\mathbf{N 2}_{\mathbf{P}} \mathbf{F}_{\mathbf{6}}$ lead to side reactions and thus lower yields of nitrene.

The spin state of the two chiral nitrene copper complexes was determined using EPR spectroscopy (Figures S1 and S2). The observed EPR spectra of the nitrene sample and the decayed species are very similar. This indicates an EPR silent nitrene species and a copper(II) decay species. Further investigation of the spin state by the Evans NMR method was not possible because of the low stability of $\mathbf{N 1 P F}_{\mathbf{6}}$, the necessary addition of acetonitrile and the slow generation of $\mathbf{N 2 P F}_{\mathbf{6}}$. Therefore, in accordance with results for previous bis(pyrazolyl)methane copper nitrene complexes [64, 65] a singlet spin state is assumed for $\mathbf{N}_{\mathbf{P}} \mathbf{P F}_{\mathbf{6}}$ and $\mathbf{N}_{\mathbf{2}} \mathbf{P} \mathbf{F}_{\mathbf{6}}$.

\subsection{Catalytic aziridination}

With both chiral copper acetonitrile complexes $\mathbf{C 1}$ and in situ formed C2, the aziridination of different styrene derivatives was performed. Different 4-substituted as well as $\beta$-substituted styrene derivatives were applied as substrates (Scheme 1, Table 2, Table S4).

The catalytic aziridination reactions were performed at room temperature with PhINTs as nitrene generating agent analogous to the previously applied protocol $[64,65]$. For the aziridination to $\beta$-substituted styrene derivatives the expected behavior [17] was observed that starting from the trans derivatives leads to pure trans products. In contrast, from the cis derivative a mixture of both isomers is obtained.

Both catalysts have an overall good activity in the aziridination of styrene derivatives. While for $\mathbf{C 1}$ a racemic product is obtained, for $\mathbf{C 2}$ a slightly enantio-enriched
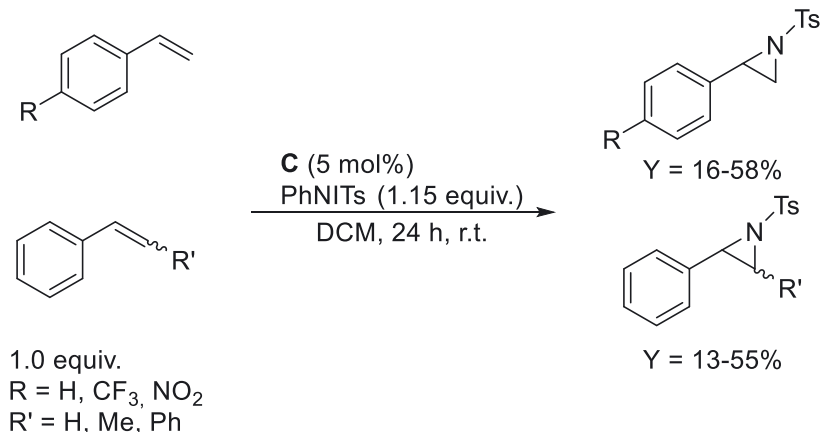

$Y=13-55 \%$ 
Table 2: Yields of the aziridination of different styrene derivatives with $\mathbf{C} 1$ and in situ formed $\mathbf{C 2}$ at room temperature (enantiomeric excess), \{cis/trans\}.

\begin{tabular}{|c|c|c|}
\hline & C1 (\%) & C2 (\%) \\
\hline Styrene & 16 & $55(4)$ \\
\hline 4- $\mathrm{CF}_{3}$-styrene & 46 & $52(10)$ \\
\hline 4- $\mathrm{NO}_{2}$-styrene & 52 & $58(8)$ \\
\hline cis-methylstyrene & $39\{33 / 67\}$ & $49\{57 / 43\}$ \\
\hline trans-methylstyrene & 38 & $55(8)$ \\
\hline cis-stilbene & - & $24\{49 / 51\}$ \\
\hline trans-stilbene & - & $13(30)$ \\
\hline
\end{tabular}

Yields were determined using ${ }^{1} \mathrm{H}$ NMR spectroscopy with nitromethane as internal standard.

product is obtained. The enantiomeric excess can be increased by adding a sterically demanding group in the $\beta$-position of the substrate, decreasing the reaction temperature from room temperature to $0^{\circ} \mathrm{C}$ or the introduction of an electron withdrawing or donating group into the substrate. For the conversion of stilbene, the highest enantiomeric excess was achieved with 30 (Table 2).

In comparison to other bis(pyrazolyl)methane copper nitrene complexes $[64,65]$ the activity of $\mathbf{C 1}$ and $\mathbf{C 2}$ is in the same range. It is remarkable that for $\beta$-substituted styrene derivatives a higher fraction of trans product is obtained starting from the cis substrate than previously reported. This indicates that an aromatically substituted pyrazolyl unit leads to a transition state with a higher singlet contribution than aliphatically substituted pyrazolyl units. Furthermore, for $\mathbf{C 1}$ a higher fraction of trans product is observed than for C2. This indicates a higher triplet contribution to the mechanism, which can be one reason for the difference in the observed enantiomeric excess for both catalysts. In comparison to other chiral copper complexes it can be observed that for styrene higher yields (63\%) and enantiomeric excess $(89 \%)$ are achievable by the use of bis(oxazoline) ligands [39].

\subsection{Catalytic $\mathrm{C}-\mathrm{H}$ amination}

With all four copper(I) complexes, the $\mathrm{C}-\mathrm{H}$ amination of different substrates was performed. Beside the prochiral substrates ethylbenzene, bibenzyl and neopentyl benzene, also cyclohexane and toluene were applied (Scheme 2, Table 3, Table S5).

The catalytic $\mathrm{C}-\mathrm{H}$ aminations were performed at room temperature with ${ }^{\mathrm{S}} \mathrm{PhINTs}$ as nitrene generating agent analogously to known protocols $[64,65]$. For the amination of benzylic substrates it was observed, that the amination occurs selectively in the benzylic position.

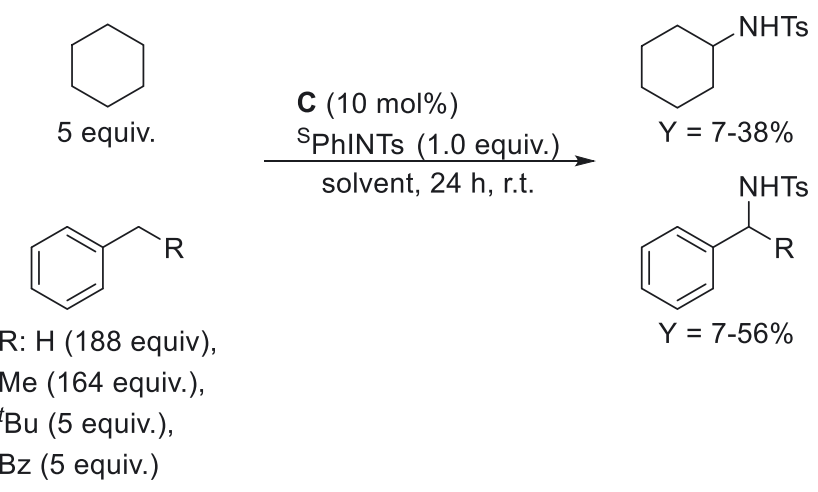

Scheme 2: C-H amination of different substrates.

The $\mathrm{C}-\mathrm{H}$ amination reactions of ethylbenzene with $\mathbf{C 3}$ and $\mathbf{C 4}$ lead to a low or no conversion of the substrate. As the complex $\mathbf{C} \mathbf{4}$ shows a low solubility in chlorobenzene, the reaction was also performed in dichloromethane with the same result (Table S5 [SI]). With $\mathbf{C 1}$ as catalyst good yields were obtained for cyclohexane, toluene and ethylbenzene, but the conversion of ethylbenzene led to a racemic product. For the application of $\mathbf{C} 2$ as catalyst, DCM was used as solvent, because the solubility of $\mathbf{C 2}$ in chlorobenzene is low. When isolated as well as in situ formed $\mathbf{C 2}$ was used, higher yields (25 and 7\%) for the isolated complex and a higher enantiomeric excess (10 and 4) were obtained. Therefore, it can be concluded that the addition of acetonitrile to $\mathbf{C 4}$ to yield $\mathbf{C 2}$ decreases the reactivity for the application in $\mathrm{C}-\mathrm{H}$ amination reactions, but not for aziridination reactions. By lowering the reaction temperature, the enantiomeric excess can be increased for the in situ formed complex from 4 to 10 . For the other substrates only a trace amount of product was observed.

In comparison to other bis(pyrazolyl)methane copper nitrene complexes $[64,65]$ the activity of $\mathbf{C 1}$ is in the same range, while the necessary change of the solvent and the addition of acetonitrile lowers the activity of $\mathbf{C 2}$ significantly. Other ligands, for example guanidines, lead to a higher activity for the $\mathrm{C}-\mathrm{H}$ amination reactions [17]. A

Table 3: Yields of the $\mathrm{C}-\mathrm{H}$ amination of different substrates with $\mathrm{C1}$ and in situ formed $\mathbf{C} 2$ at room temperature (enantiomeric excess).

\begin{tabular}{lrl}
\hline & C1 (\%) & C2 (\%) \\
\hline Cyclohexane & 38 & 7 \\
Toluene & 56 & 8 \\
Ethylbenzene & 43 & $7(4)$ \\
Bibenzyl & - & Traces \\
Neopentyl benzene & - & Traces \\
\hline
\end{tabular}

Yields were determined using ${ }^{1} \mathrm{H}$ NMR spectroscopy with nitromethane as internal standard. 
variety of different metal complexes were applied as catalyst for the nitrene mediated asymmetric $\mathrm{C}-\mathrm{H}$ amination [79]. However, no chiral copper complexes were found for the nitrene mediated asymmetric $\mathrm{C}-\mathrm{H}$ amination reaction and only a few examples [80] are presented for other asymmetric $\mathrm{C}-\mathrm{H}$ amination reactions.

\section{Conclusions}

In this study, two novel terminal, chiral bis(pyrazolyl)methane copper tosyl nitrene complexes have been synthesized and characterized in terms of their stoichiometry, yield, thermal stability, reactivity, and spectroscopic features using UV/Vis and EPR spectroscopy. The ligand design was varied regarding different aspects, and three novel bis(pyrazolyl)methane ligands were prepared which have different chiral pyrazolyl units or substituents on the pyridinyl group, with the chiral pyrazolyl units based on pulegone and camphor. With these ligands four copper(I) complexes were obtained. Two of these four copper(I) complexes were successfully applied to the synthesis of two novel nitrene complexes. Furthermore, it was shown that with the two novel chiral copper nitrene complexes aziridinations of styrene derivatives can be carried out with good yields and $\mathrm{C}-\mathrm{H}$ aminations are also possible under mild reaction conditions. It was shown that with the camphor-based ligand enantiomerically enriched products are achieved with an enantiomeric excess of up to 30, while the pulegone-based ligand only gives racemic products. As asymmetric copper-mediated $\mathrm{C}-\mathrm{H}$ aminations are rare, the approach presented here is a first step for the development of more enantioselective catalysts.

\section{Experimental section}

\subsection{General}

All manipulations were carried out under nitrogen atmosphere. $\mathrm{Ni}$ trogen was dried by passage through $\mathrm{P}_{2} \mathrm{O}_{5}$. All solvents used were dried and degassed by standard literature procedures [81] prior to use. All chemicals were purchased from commercial suppliers and used without further purification. Ferrocene was sublimed prior to use. Molecular sieves $\left(3 \AA\right.$ A ) were activated under vacuum at $220^{\circ} \mathrm{C}$ for $20 \mathrm{~h}$.

The starting materials (4R,7S)-7-(tert-butyl)-4-methyl-4,5,6,7tetrahydro- $2 H$-indazole (PulPz) [82], (4S,7R)-7,8,8-trimethyl-4,5,6,7tetrahydro-2H-4,7-methanoindazole (CamPz) [82], [Cu(MeCN) $\left.{ }_{4}\right] \mathrm{PF}_{6}$ [83], (2-tert-butylsulfonyl)(p-toluenesulfonyl)iminoiodo-benzene ( $\left.{ }^{\mathrm{S}} \mathrm{PhINTs}\right)$ [59], (2-tert-butylsulfonyl)(diacetoxyiodo)benzene [84] and ( $p$-toluenesulfonyl)iminoiodobenzene (PhINTs) [85] were synthesised according to literature.
NMR spectra were recorded on a Bruker Avance III HD 400 or a Bruker Avance II 400 spectrometer at $25{ }^{\circ} \mathrm{C} .{ }^{1} \mathrm{H}$ and ${ }^{13} \mathrm{C}\left\{{ }^{1} \mathrm{H}\right\}$ NMR signals are given relative to the deuterated solvents as an internal standard. Chemical shifts were assigned with the use of two-dimensional NMR experiments (COSY, HSQC, HMBC). The enantiomeric excess was determined by ${ }^{1} \mathrm{H}$ NMR with the help of $\left[\mathrm{Eu}(\mathrm{hfc})_{3}\right]$ in $\mathrm{C}_{6} \mathrm{D}_{6}$. NMR data of the ligands and complexes were deposited as original data in the repository Chemotion [86] and are published under an Open Access model. The link is given in the analytical description. FT-IR spectra were recorded on a SHIMADZU IRTracer 100 using a CsI beam splitter in combination with an ATR unit (Quest model from Specac utilising a robust monolithic crystalline diamond) in a resolution of $2 \mathrm{~cm}^{-1}$. ESI mass spectra were obtained with a THERMOFISHER SCIENTIFIC LTQ Orbitrap XL. The source voltage was $4.49 \mathrm{kV}$ and the capillary temperature was $299.54^{\circ} \mathrm{C}$. The tube lens voltage was set between 110 and $130 \mathrm{~V}$. UV/Vis spectra were recorded with a Cary 60 spectrophotometer from AGILENT TECHNOLoGIES connected via a Cary 50 fiber optic coupler in combination with a fibre-optic quartz glass immersion probe (HeLLMA, $1 \mathrm{~mm}$ ) in a customized Schlenk measurement cell. Thin layer chromatography sheets were received from MACHERY-NAGEL with a layer thickness of $0.20 \mathrm{~mm}$ and a precoating of a fluorescent indicator. Column chromatography was performed with Geduran silica gel $60(40-63 \mu \mathrm{m})$ from MeRCK or with alumina B, activity Super I from MP BiomEDICALS. EPR spectra were recorded at $77 \mathrm{~K}$ on a Miniscope MS 400 from MAGNETTECH with a microwave frequency of $9.4 \mathrm{GHz}$. The concentration of the measured frozen solution was $10 \mathrm{~mm}$ regarding the copper concentration. The $B_{0}$ field was adjusted to $325 \mathrm{mT}$ with a range of $160 \mathrm{mT}(245-405 \mathrm{mT})$ and a sweep time of $60 \mathrm{~s}$. Further parameters were adjusted as follows: smooth $=0.100 \mathrm{~s}, \mathrm{NOPs}=4096$, gain mantissa $=5$, gain exponent $=1$ and $\mathrm{MW}_{\text {attend. }}=10$. The obtained EPR spectra were simulated using the comprehensive software packet EAsYSPIN (version 5.2.28) [87]. The cyclic voltammetric measurements were performed at room temperature with a Метroнm Autolab PGSTAT 101 potentiostat with a three-electrode arrangement with a Pt disc working electrode (1 $\mathrm{mm}$ diameter), an $\mathrm{Ag}$ wire pseudo reference electrode and a glassy-carbon counter electrode under inert conditions. The samples were prepared with a 0.5-1.0 mM concentration of analyte and $0.1 \mathrm{M} \mathrm{N}^{n} \mathrm{Bu}_{4} \mathrm{PF}_{6}$ as supporting electrolyte in dichloromethane. Ferrocene was added as internal standard after each measurement. All potentials are referenced relative to the $\mathrm{Fc} / \mathrm{Fc}^{+}$couple. The cyclic voltammograms were measured with sweep rates of 20,50 , 100 and $200 \mathrm{mV} \mathrm{s}^{-1}$.

The crystallographic data for $\mathbf{C 1}, \mathbf{C} 3$ and $\mathbf{C 4}$ is presented in Table S6 in the Supplementary material. The data of C1, C3 and C4 was collected with a Bruker D8 goniometer with APEX CCD detector using an Incoatec microsource with MoK $\alpha$ radiation $(\lambda=0.71073 \AA$ A $)$. Temperature control was achieved with an Oxford Cryostream 700. Crystals were mounted with grease on glass fibers and data were collected at $T=100 \mathrm{~K}$ in $\omega$-scan mode. Data were collected with SMART [88], integrated with SAINT [88] and corrected for absorption by multi-scan methods with SADABS [88].

The structure was solved by direct and conventional Fourier methods and all non-hydrogen atoms were refined anisotropically with full-matrix least-squares based on $F^{2}$ (XPREP [89], SheLXS [90], ShelXT [91], ShelXL [92], and ShelXLe [93]). Hydrogen atoms were derived from different Fourier maps and placed at idealized positions, riding on their parent $\mathrm{C}$ atoms, with isotropic displacement parameters $U_{\text {iso }}(\mathrm{H})=1.2 U_{\text {eq }}(\mathrm{C})$ and $1.5 U_{\text {eq }}(\mathrm{C}$ methyl). All methyl groups were allowed to rotate but not to tip.

The asymmetric unit of $\mathbf{C} \mathbf{4}$ features two large voids, each characterized by a volume of ca. $394 \AA^{3}$ and an electron content of ca. 102 
electrons, in good agreement with the requirements for two molecules of disordered pentane per void. As no model with atomic resolution for the co-crystallized solvent molecules could be derived, their contribution of the structure factors was taken into account with the SQUEEZE procedure as incorporated in PLATON $[94,95]$.

Full crystallographic data for $\mathbf{C 1}, \mathbf{C} 3$ and $\mathbf{C 4}$ have been deposited with the Cambridge Crystallographic Data Centre as supplementary no. CCDC 2065189 for C1, CCDC 2065190 for C3 and CCDC 2065191 for C4. Copies of the data can be obtained free of charge on application to CCDC, 12 Union Road, Cambridge CB2 1EZ, UK (fax: (+44)1223-336-033; e-mail:deposit@ccdc.cam.ac.uk).

\subsection{Synthesis and characterization}

4.2.1 Synthesis of $\left(4 R, 4^{\prime} R, 7 S, 7^{\prime} S\right)$-2,2'-(pyridin-2-ylmethylene)bis(7(tert-butyl)-4-methyl-4,5,6,7-tetrahydro-2H-indazole) $\left\{\mathrm{HC}(\mathrm{PulPz})_{2} \mathrm{Py}\right\}$ (L1): PulPz (4.000 g, 20.8 mmol, 2 equiv.) was added gradually to a suspension of $\mathrm{NaH}(0.513 \mathrm{~g}, 21.3 \mathrm{mmol}, 2$ equiv. $)$ in $\mathrm{THF}(50 \mathrm{~mL})$ at $0{ }^{\circ} \mathrm{C}$. After stirring at $0{ }^{\circ} \mathrm{C}$ until no more gas formation was observed, approximated $30 \mathrm{~min}, \mathrm{SOCl}_{2}(0.76 \mathrm{~mL}, 10.4 \mathrm{mmol}, 1$ equiv. $)$ was added dropwise. After stirring at $0{ }^{\circ} \mathrm{C}$ for 30 and $45 \mathrm{~min}$ at room temperature, picolinaldehyde (0.99 mL, $10.4 \mathrm{mmol}, 1$ equiv.) and $\mathrm{CoCl}_{2}(0.130 \mathrm{~g}$, $1.0 \mathrm{mmol}, 10 \mathrm{~mol} \%$ ) were added and the reaction mixture was refluxed for $72 \mathrm{~h}$. Following cooling to room temperature, the reaction was stopped with water and diethyl ether $(1 / 1,20 \mathrm{~mL})$. The aqueous phase was extracted with diethyl ether $(3 \times 10 \mathrm{~mL})$, the combined organic phases were dried over $\mathrm{Na}_{2} \mathrm{SO}_{4}$ and concentrated in vacuo. The residue was purified by silica gel column chromatography (iso-hexane/ethyl acetate, $\left.8 / 5, R_{\mathrm{f}}=0.70\right)$ to give $\mathrm{HC}(\mathrm{PulPz})_{2} \mathrm{Py}(3.61 \mathrm{~g}, 7.6 \mathrm{mmol}, 73 \%)$ as a light yellowish oil.

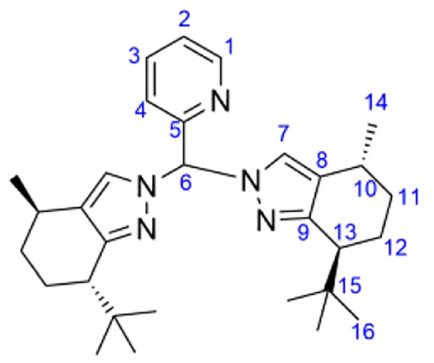

Chemical formula: $\mathrm{C}_{30} \mathrm{H}_{43} \mathrm{~N}_{5}$. Molecular mass: $473.71 \mathrm{~g} \mathrm{~mol}^{-1}-{ }^{1} \mathrm{H}$ $\operatorname{NMR}\left(\mathrm{CD}_{2} \mathrm{Cl}_{2}, 400 \mathrm{MHz}\right): \delta=8.58\left(\mathrm{qd},{ }^{3} J=4.8 \mathrm{~Hz},{ }^{4} \mathrm{~J}=0.8 \mathrm{~Hz}, 1 \mathrm{H}, \mathrm{H}-1\right)$, $7.70\left(\mathrm{dt},{ }^{3} \mathrm{~J}=8.0 \mathrm{~Hz},{ }^{4} \mathrm{~J}=1.6 \mathrm{~Hz}, 1 \mathrm{H}, \mathrm{H}-3\right), 7.45$ (s, $\left.1 \mathrm{H}, \mathrm{H}-6\right), 7.27$ (m, 3H, $\mathrm{H}-2, \mathrm{H}-7), 6.99\left(\mathrm{~d},{ }^{3} \mathrm{~J}=7.6 \mathrm{~Hz}, 1 \mathrm{H}, \mathrm{H}-4\right), 2.54$ (m, 4H, H-10, H-13), 2.01 (m, 2H, H-12), 1.89 (m, 2H, H-11), 1.42 (m, 2H, H-12), 1.22 (m, 2H-11), 1.12 (2× $\left.\mathrm{d},{ }^{3} \mathrm{~J}=6.4 \mathrm{~Hz}, 6 \mathrm{H}, \mathrm{H}-14\right), 0.99(2 \times \mathrm{s}, 18 \mathrm{H}, \mathrm{H}-16) \mathrm{ppm}-{ }^{13} \mathrm{C}\left\{{ }^{1} \mathrm{H}\right\} \mathrm{NMR}$ $\left(\mathrm{CD}_{2} \mathrm{Cl}_{2}, 100 \mathrm{MHz}\right): \delta=157.0$ (C-5), 152.7 (d, C-8), 149.9 (C-1), $137.3(\mathrm{C}-3)$, 126.0 (d, C-9), 125.9 (d, C-7), 124.0 (C-2), 122.6 (C-4), 79.4 (C-6), 45.5 (d, C-12), 34.6 (d, C-15), 33.9 (d, C-11), 29.0 (C-10), 28.3 (C-16), 26.8 (d, C-13), 21.7 (d, C-14) ppm. Note: The doublets are due to the asymmetry of the pyrazolyl units, therefore no J couplings are given. - HRMS ((+)-ESI, $\mathrm{MeOH}): m / z$ (found): 496.3404 (100\%), 497.3441 (32\%), 498.3478 (5\%); $m / z$ (calc.): $496.3444\left(100 \%,{ }^{23} \mathrm{Na}_{1}{ }^{12} \mathrm{C}_{30}{ }^{1} \mathrm{H}_{43}{ }^{14} \mathrm{~N}_{5}{ }^{+}\right), 497.3441$ (32\%, $\left.{ }^{23} \mathrm{Na}_{1}{ }^{12} \mathrm{C}_{29}{ }^{13} \mathrm{C}_{1}{ }^{1} \mathrm{H}_{43}{ }^{14} \mathrm{~N}_{5}{ }^{+}\right), 498.3478\left(5 \%,{ }^{23} \mathrm{Na}_{1}{ }^{12} \mathrm{C}_{28}{ }^{13} \mathrm{C}_{2}{ }^{1} \mathrm{H}_{43}{ }^{14} \mathrm{~N}_{5}{ }^{+}\right)$. - IR (ATR, neat), $\tilde{v}\left(\mathrm{~cm}^{-1}\right)$ : 2952 (m), 2865 (m), 1740 (vw), 1590 (w), 1574 (w), 1564 (w), 1479 (w), 1436 (m), 1420 (m), 1392 (m), 1363 (s), $1333(\mathrm{w}), 1306$ (m), $1239(w), 1219(w), 1198(w), 1172(m), 1148(m), 1110(w), 1094(w)$, $1050(\mathrm{w}), 1030(\mathrm{w}), 1011(\mathrm{~m}), 994(\mathrm{w}), 960(\mathrm{w}), 940(\mathrm{vw}), 885(\mathrm{~m}), 869$ (w), $848(\mathrm{w}), 824(\mathrm{~m}), 798(\mathrm{~m}), 762(\mathrm{~m}), 748(\mathrm{vs}), 678(\mathrm{~m}), 664(\mathrm{w}), 619$ (w), 568 (vw), 516 (vw), 503 (vw), 481 (vw), 474 (vw).

Additional information on the NMR of the target compound including original data files is available via Chemotion Repository: https://dx.doi.org/10.14272/NWKTUCNDIPMMKM-TZYAJKAJSAN.1

4.2.2 Synthesis of $\left.\left(4 S, 4^{\prime} S, 7 R, 7^{\prime} R\right)-2,2^{\prime}\right)$-(pyridin-2-ylmethylene)bis (7,8,8-trimethyl-4,5,6,7-tetrahydro-2H-4,7-methanoindazole)

$\left\{\mathrm{HC}(\mathrm{CamPz}){ }_{2} \mathbf{P y}\right\}$ (L2): The Ligand $\mathbf{L} 2$ was synthesized analogous to $\mathbf{L 1}$. CamPz (3.71 g, $21.0 \mathrm{mmol}, 2$ equiv.) and picolinaldehyde $(1.0 \mathrm{~mL}$, $10.5 \mathrm{mmol}, 1$ equiv.) were used in THF $(30 \mathrm{~mL})$. The reaction mixture was refluxed overnight. The residue was purified by silica gel column chromatography (iso-hexane/ethyl acetate/dichloromethane, 1/1/1, $R_{\mathrm{f}}=0.55$ ) and alumina column chromatography (ethyl acetate/ dichloromethane, $\left.1 / 5, R_{\mathrm{f}}=0.81\right)$ to give $\mathrm{HC}(\mathrm{CamPz})_{2} \mathrm{Py}(1.20 \mathrm{~g}$, $2.7 \mathrm{mmol}, 26 \%$ ) as a colorless solid.

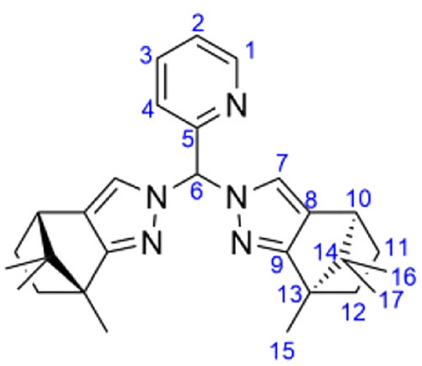

Chemical formula: $\mathrm{C}_{28} \mathrm{H}_{35} \mathrm{~N}_{5}$. Molecular mass: $441.29 \mathrm{~g} \mathrm{~mol}^{-1}-{ }^{1} \mathrm{H}$ $\operatorname{NMR}\left(\mathrm{CD}_{2} \mathrm{Cl}_{2}, 400 \mathrm{MHz}\right): \delta=8.58\left(\mathrm{dq},{ }^{3} J=4.8 \mathrm{~Hz},{ }^{4} J=0.8 \mathrm{~Hz}, 1 \mathrm{H}, \mathrm{H}-1\right), 7.70$ (td, ${ }^{3} J=7.8 \mathrm{~Hz},{ }^{4} \mathrm{~J}=1.8 \mathrm{~Hz}, 1 \mathrm{H}, \mathrm{H}-3$ ), 7.44 (s, $\left.1 \mathrm{H}, \mathrm{H}-6\right), 7.27$ (qd, ${ }^{3} J=4.8 \mathrm{~Hz}$, $\left.{ }^{4} J=0.9 \mathrm{~Hz}, 1 \mathrm{H}, \mathrm{H}-2\right), 7.00$ (s, $\left.1 \mathrm{H}, \mathrm{H}-7\right), 6.95$ (s, $\left.1 \mathrm{H}, \mathrm{H}-7\right), 6.93\left(\mathrm{dq},{ }^{3} J=7.8 \mathrm{~Hz}\right.$, $\left.{ }^{4} J=0.8 \mathrm{~Hz}, 1 \mathrm{H}, \mathrm{H}-4\right), 2.74\left(2 \times \mathrm{d},{ }^{3} \mathrm{~J}=4.3 \mathrm{~Hz}, 2 \mathrm{H}, \mathrm{H}-10\right), 2.06$ (m, 2H, H-11), 1.84 (m, 2H, H-12), 1.28 (m, 2H, H-12), 1.22 (s, 3H, H-15), 1.21 (s, 3H, H-15), 1.14 (m, 2H, H-11), 0.94 (2 × s, $2 \times 3 \mathrm{H}, \mathrm{H}-16 / 17), 0.66$ (s, 3H, H-16/17), 0.63 (s, 3H, H-16/17) ppm $-{ }^{13} \mathrm{C}\left\{{ }^{1} \mathrm{H}\right\}$ NMR $\left(\mathrm{CD}_{2} \mathrm{Cl}_{2}, 100 \mathrm{MHz}\right): \delta=168.0$ (d, C-9), 157.3 (C-5), 149.9 (C-1), 137.5 (C-3), 128.1 (d, C-8), 123.9 (C-2), 122.5 (C-4), 122.2 (d, C-7), 79.0 (C-6), 60.8 (C-14), 50.8 (C-13), 47.8 (d, C-10), 34.3 (d, C-12), 28.2 (d, C-11), 20.9 (d, C-16/17), 19.4 (C-16/17), 11.0 (d, C-15) ppm. Note: The doublets are due to the asymmetry of the pyrazolyl units, therefore no J couplings are given. - HRMS ((+)-ESI, MeOH): $\mathrm{m} / z$ (found): 464.27795 (100\%), 465.28122 (29\%), 466.28467 (4\%); $m / z$ (calc.) = $464.27902(100 \%$, $\left.{ }^{23} \mathrm{Na}_{1}{ }^{12} \mathrm{C}_{28}{ }^{1} \mathrm{H}_{35}{ }^{14} \mathrm{~N}_{5}{ }^{+}\right), 465.28237\left(30 \%,{ }^{23} \mathrm{Na}_{1}{ }^{12} \mathrm{C}_{27}{ }^{13} \mathrm{C}_{1}{ }_{1} \mathrm{H}_{38}{ }^{14} \mathrm{~N}_{5}{ }^{+}\right) \quad 466.28573$ (4\%, ${ }^{23} \mathrm{Na}_{1}{ }^{12} \mathrm{C}_{26}{ }^{13} \mathrm{C}_{2}{ }^{1} \mathrm{H}_{38}{ }^{14} \mathrm{~N}_{5}^{+}$). - IR (ATR, neat), $\tilde{v}\left(\mathrm{~cm}^{-1}\right)$ : 2965 (s), $2865(\mathrm{w})$, 1590 (m), 1572 (w), 1485 (w), $1472(\mathrm{~m}), 1457$ (w), 1437 (m), 1418 (w), 1385 (m), 1376 (s), 1366 (vs), 1342 (w), 1324 (m), 1288 (s), 1277 (vs), 1268 (m), 1238 (vw), 1227 (vw), 1210 (w), 1181 (m), 1141 (m), 1120 (s), 1107 (vw), 1093 (w), $1085(\mathrm{w}), 1050(\mathrm{vw}), 998(\mathrm{w}), 969(\mathrm{w}), 963$ (w), 950 (vs), $909(\mathrm{w}), 881(\mathrm{~m})$, $862(\mathrm{w}), 816(\mathrm{w}), 805$ (m), $783(\mathrm{vs}), 771$ (vs), $748(\mathrm{~m}), 718(\mathrm{w}), 698(\mathrm{~m}), 667$ (m), $640(\mathrm{w}), 620$ (vs), $610(\mathrm{~s}), 570(\mathrm{w})$.

Additional information on the NMR of the target compound including original data files is available via Chemotion Repository:

https://dx.doi.org/10.14272/KXRYDZCNUHBCQB-SJWRPRNESAN.1

4.2.3 Synthesis of methyl 6-(bis(3-(tert-butyl)-1H-pyrazol-1-yl) methyl) picolinate $\left\{\mathrm{HC}\left({ }^{t} \mathrm{BuPz}\right)_{2}\left(6-\mathrm{CO}_{2} \mathrm{MePy}\right)\right\}$ (L3): The Ligand $\mathbf{L 3}$ was synthesized analogous to L1. 3-tert-butylpyrazole (1.504 g, $12.1 \mathrm{mmol}, 2$ equiv.) and 6-formyl-2-pyridinecarboxylate $(1.000 \mathrm{~g}$, 
$6.1 \mathrm{mmol}, 1$ equiv.) were used in THF $(20 \mathrm{~mL})$. The reaction mixture was refluxed for $24 \mathrm{~h}$. The residue was purified by silica gel column chromatography (iso-hexane/ethyl acetate, $7 / 3, R_{\mathrm{f}}=0.56$ ) to give $\mathrm{HC}\left({ }^{t} \mathrm{BuPz}\right)_{2}\left(6-\mathrm{CO}_{2} \mathrm{MePy}\right)(1.41 \mathrm{~g}, 3.6 \mathrm{mmol}, 59 \%)$ as a colorless solid.<smiles></smiles>

Chemical formula: $\mathrm{C}_{22} \mathrm{H}_{29} \mathrm{~N}_{5} \mathrm{O}_{2}$. Molecular mass: $395.51 \mathrm{~g} \mathrm{~mol}^{-1}-{ }^{1} \mathrm{H}$ NMR $\left(\mathrm{CD}_{2} \mathrm{Cl}_{2}, 400 \mathrm{MHz}\right): \delta=8.09\left(\mathrm{~d},{ }^{3} J=7.9 \mathrm{~Hz}, 1 \mathrm{H}, \mathrm{H}-2\right), 7.88(\mathrm{t}$, $\left.{ }^{3} J=7.9 \mathrm{~Hz}, 1 \mathrm{H}, \mathrm{H}-3\right), 7.56(\mathrm{~s}, 1 \mathrm{H}, \mathrm{H}-6), 7.38\left(\mathrm{~d},{ }^{3} J=2.4 \mathrm{~Hz}, 2 \mathrm{H}, \mathrm{H}-7\right), 7.21(\mathrm{~d}$, $\left.{ }^{3} J=7.9 \mathrm{~Hz}, 1 \mathrm{H}, \mathrm{H}-4\right), 6.20$ (d, $\left.{ }^{3} \mathrm{~J}=2.4 \mathrm{~Hz}, 2 \mathrm{H}, \mathrm{H}-8\right), 3.96$ (s, 3H, H-11), 1.28 (s, 18H, H-13) ppm ${ }^{13} \mathrm{C}\left\{{ }^{1} \mathrm{H}\right\}$ NMR $\left(\mathrm{CD}_{2} \mathrm{Cl}_{2}, 100 \mathrm{MHz}\right): \delta=165.4(\mathrm{C}-10)$, 164.0 (C-9), 156.6 (C-5), 148.5 (C-1), 138.7 (C-3), 130.4 (C-7), 126.1 (C-4), 125.6 (C-2), 103.7 (C-8), 79.0 (C-6), 53.3 (C-11), 32.7 (C-12), 30.8 (C-13) ppm - HRMS ((+)-ESI, MeOH): $m / z$ (found) $=418.22119(100 \%)$, $419.22437(23 \%), 420.22760$ (3\%) $\mathrm{m} / z$ (calc.) $=418.22189(100 \%$, $\left.{ }^{23} \mathrm{Na}^{12} \mathrm{C}_{22}{ }^{1} \mathrm{H}_{29}{ }^{14} \mathrm{~N}_{5}{ }^{16} \mathrm{O}_{2}{ }^{+}\right), \quad 419.22525 \quad\left(24 \%, \quad{ }^{23} \mathrm{Na}^{12} \mathrm{C}_{21}{ }^{13} \mathrm{C}_{1}{ }^{1} \mathrm{H}_{29}{ }^{14} \mathrm{~N}_{5}{ }^{16} \mathrm{O}_{2}{ }^{+}\right)$, $420.22860\left(3 \%,{ }^{23} \mathrm{Na}^{12} \mathrm{C}_{20}{ }^{13} \mathrm{C}_{2} \mathrm{H}_{29}{ }^{14} \mathrm{~N}_{5}{ }^{16} \mathrm{O}_{2}{ }^{+}\right)$. - IR (ATR), $\tilde{v}\left(\mathrm{~cm}^{-1}\right): 2958(\mathrm{w})$, 2931 (vw), 2902 (w), 2867 (vw), 1751 (w), 1722 (m), 1701 (w), 1590 (w), 1577 (w), 1519 (m), 1459 (w), 1437 (w), 1397 (vw), 1362 (w), 1309 (m), 1263 (w), $1248(\mathrm{~m}), 1225(\mathrm{w}), 1161(\mathrm{w}), 1137(\mathrm{~m}), 1091(\mathrm{w}), 1056(\mathrm{~m}), 996(\mathrm{w}), 982(\mathrm{w})$, 914 (w), 820 (w), 804 (m), 781 (w), 755 (vs), 695 (w), 643 (w).

Additional information on the NMR of the target compound including original data files is available via Chemotion Repository:

https://dx.doi.org/10.14272/TZHOOUXJQHQALI-UHFFFAOYSAN.1

4.2.4 Synthesis of $\left[\mathrm{Cu}\left\{\mathrm{HC}(\mathrm{PulPz})_{2} \mathrm{Py}\right\}(\mathrm{MeCN})\right] \mathrm{PF}_{6}(\mathrm{C} 1)$ : A solution of $\mathrm{HC}(\mathrm{PulPz})_{2} \mathrm{Py}(380 \mathrm{mg}, 0.80 \mathrm{mmol}, 1$ equiv.) in acetone $(20 \mathrm{~mL})$ was added dropwise over $25 \mathrm{~min}$ to a solution of $\left[\mathrm{Cu}(\mathrm{MeCN})_{4}\right] \mathrm{PF}_{6}(300 \mathrm{mg}$, $0.80 \mathrm{mmol}, 1$ equiv.) in acetone $(20 \mathrm{~mL})$. The solution was stirred for $72 \mathrm{~h}$ at room temperature. The solution was concentrated under reduced pressure to approximate the half volume and layered with hexane $(50 \mathrm{~mL})$. Overnight greenish crystals formed, which were collected by filtration and washed with hexane to yield $[\mathrm{Cu}$ $\left.\left\{\mathrm{HC}(\mathrm{PulPz})_{2} \mathrm{Py}\right\}(\mathrm{MeCN})\right] \mathrm{PF}_{6}$ (497 mg, $0.69 \mathrm{mmol}, 86 \%$ ).

The crystals obtained from this synthesis where suitable for X-ray diffraction.

A low concentration and a slow addition of the ligand solution is necessary to avoid the formation of a $\left[\mathrm{Cu}_{2} \boldsymbol{L}_{2}\right]\left(\mathrm{PF}_{6}\right)_{2}$ coordination motif.

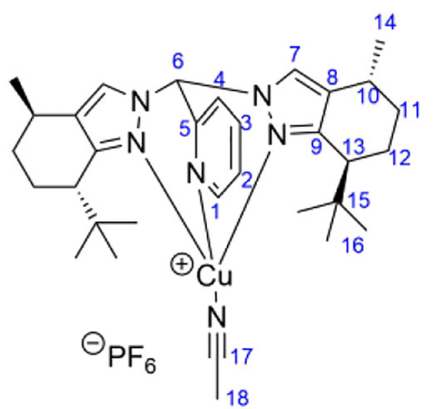

Chemical formula: $\mathrm{C}_{32} \mathrm{H}_{46} \mathrm{CuF}_{6} \mathrm{~N}_{6} \mathrm{P}$. Molecular mass: $723.27 \mathrm{~g} \mathrm{~mol}^{-1}$ ${ }^{1} \mathrm{H} \mathrm{NMR}\left(\mathrm{CD}_{2} \mathrm{Cl}_{2}, 400 \mathrm{MHz}\right): \delta=8.56\left(\mathrm{~d},{ }^{3} J=4.8 \mathrm{~Hz}, 1 \mathrm{H}, \mathrm{H}-1\right), 7.94(\mathrm{~m}, 2 \mathrm{H}$, H-3, H-4), 7.61 (d, ${ }^{3} J=6.8 \mathrm{~Hz}, 2 \mathrm{H}, \mathrm{H}-7$ ), 7.49 (m, 2H, H-2, H-6), 2.66 (t, ${ }^{3} J=8.0 \mathrm{~Hz}, 2 \mathrm{H}, \mathrm{H}-13$ ), 2.50 (m, 2H, H-10), 2.34 (s, 3H, H-18), 1.90 (m, 2H, $\mathrm{H}-12), 1.84$ (m, 2H, H-11), 1.67 (m, 2H, H-12), 1.08 (2× s, 6H, H-14), 0.96 (m, $2 \mathrm{H}, \mathrm{H}-11), 0.82(2 \times \mathrm{s}, 18 \mathrm{H}, \mathrm{H}-16) \mathrm{ppm}-{ }^{13} \mathrm{C}\left\{{ }^{1} \mathrm{H}\right\} \mathrm{NMR}\left(\mathrm{CD}_{2} \mathrm{Cl}_{2}, 100 \mathrm{MHz}\right)$ : $\delta=154.6$ (C-5), 153.5 (C-8), 152.6 (C-17), 149.3 (C-1), 139.9 (C-3), 128.5 (d, C-7), 126.9 (d, C-9), 125.8 (C-2), 125.4 (C-4), 73.0 (d, C-6), 43.1 (d, C-13), 36.3 (d, C-15), 32.9 (d, C-11), 28.6 (d, C-16), 27.9 (d, C-10), 25.0 (d, C-12), 21.3 (d, $\mathrm{C}-14), 3.4$ (C-18) ppm. Note: The doublets are due to the asymmetry of the pyrazolyl units, therefore no J couplings are given. $-{ }^{19} \mathrm{~F}\left\{{ }^{1} \mathrm{H}\right\} \mathrm{NMR}\left(\mathrm{CD}_{2} \mathrm{Cl}_{2}\right.$, $377 \mathrm{MHz}): \delta=-73.1(\mathrm{~d}, J=711 \mathrm{~Hz}) \mathrm{ppm}-{ }^{31} \mathrm{P}\left\{{ }^{1} \mathrm{H}\right\} \operatorname{NMR}\left(\mathrm{CD}_{2} \mathrm{Cl}_{2}, 162 \mathrm{MHz}\right)$ : $\delta=144.1$ (sept, $J=715 \mathrm{~Hz}$ ) ppm - HRMS ((+)-ESI, MeOH): $m / z$ (found): 536.2807 (100\%), 537.2838 (35\%), 538.2830 (44\%), 539.2821 (14\%); $\mathrm{m} / z$ (calc.): $536.2814 \quad\left(100 \%,{ }^{12} \mathrm{C}_{30}{ }^{1} \mathrm{H}_{43}{ }^{63} \mathrm{Cu}_{1}{ }^{14} \mathrm{~N}_{5}{ }^{+}\right), \quad 537.2848 \quad\left(32 \%,{ }^{12} \mathrm{C}_{29}\right.$ $\left.{ }^{13} \mathrm{C}_{1}^{1} \mathrm{H}_{43}{ }^{63} \mathrm{Cu}_{1}{ }^{14} \mathrm{~N}_{5}^{+}\right), 538.2796\left(44 \%,{ }^{12} \mathrm{C}_{30}{ }^{1} \mathrm{H}_{43}{ }^{65} \mathrm{Cu}_{1}{ }^{14} \mathrm{~N}_{5}^{+}\right), 539.2830(14 \%$, ${ }^{12} \mathrm{C}_{29}{ }^{13} \mathrm{C}_{1}{ }^{1} \mathrm{H}_{43}{ }^{65} \mathrm{Cu}_{1}^{14} \mathrm{~N}_{5}{ }^{+}$). - IR (ATR, neat), $\tilde{v}\left(\mathrm{~cm}^{-1}\right): 2969$ (w), 2873 (vw), 1704 (vw), 1600 (w), 1479 (w), 1450 (w), 1429 (w), 1396 (w), 1366 (w), 1310 (w), 1300 (vw), 1282 (vw), 1217 (w), 1165 (w), 1150 (w), 1089 (vw), 1036 (vw), 1016 (w), 997 (w), 907 (vw), $879(\mathrm{w}), 867$ (w), 834 (vs), 780 (w), 767 (m), $761(\mathrm{w}), 738(\mathrm{w}), 729(\mathrm{vw}), 721(\mathrm{w}), 682(\mathrm{w}), 664(\mathrm{w}), 637(\mathrm{w}), 556(\mathrm{~s})$. Additional information on the NMR of the target compound including original data files is available via Chemotion Repository:

https://dx.doi.org/10.14272/IOWUBGJSYWBQTK-SPFGKSOKSAN.1

4.2.5 Synthesis of $\left[\mathrm{Cu}\left\{\mathrm{HC}(\mathrm{CamPz})_{2} \mathrm{Py}\right\}(\mathrm{MeCN})\right] \mathrm{PF}_{6}(\mathrm{C} 2)$ : A solution of $\mathrm{HC}(\mathrm{CamPz})_{2} \mathrm{Py}(22.1 \mathrm{mg}, 0.05 \mathrm{mmol}, 1$ equiv. $)$ in THF $(2 \mathrm{~mL})$ was added slowly dropwise to a solution of $\left[\mathrm{Cu}(\mathrm{MeCN})_{4}\right] \mathrm{PF}_{6}(18.6 \mathrm{mg}, 0.05 \mathrm{mmol}$, 1 equiv.) in THF ( $2 \mathrm{~mL}$ ). The solution was stirred for $10 \mathrm{~min}$. Diethyl ether $(15 \mathrm{~mL})$ was added and a precipitate formed, which was collected by filtration and washed with diethyl ether to yield $\left[\mathrm{Cu}\left\{\mathrm{HC}(\mathrm{CamPz})_{2}\right.\right.$ $\mathrm{Py}\}(\mathrm{MeCN}) \mathrm{PF}_{6}$ (29.7 mg, $0.04 \mathrm{mmol}, 80 \%$ ).

A low concentration and a very slow addition of the ligand solution is necessary to avoid the formation of a $\left[\mathrm{Cu}_{2} \mathrm{~L}_{2}\right]\left(\mathrm{PF}_{6}\right)_{2}$ coordination motif. The formation of the title compound is implicated by a pale yellowish color of the solution and a precipitate, while the formation of a $\left[\mathrm{Cu}_{2} \mathrm{~L}_{2}\right]\left(\mathrm{PF}_{6}\right)_{2}$ coordination motif is implicated by an intense yellow color of the solution and a precipitate. Trials to scale up the reaction were not successful. When the title compound is dissolved the formation of a $\left[\mathrm{Cu}_{2} \boldsymbol{L}_{2}\right]\left(\mathrm{PF}_{6}\right)_{2}$ coordination motif can be observed, which can be reversed by the dropwise addition of about 10-20 equiv. of acetonitrile to the solution. The addition of too much acetonitrile leads to the formation of $\left[\mathrm{Cu}(\mathrm{MeCN})_{4}\right] \mathrm{PF}_{6}$, this is implicated by a complete loss of color of the solution.

This complex was additionally synthesized in situ from C4.

Acetonitrile $(0.26 \mathrm{~mL}, 5 \mathrm{mmol}, 20$ equiv.) was added to a solution of C4 (325 mg, $0.25 \mathrm{mmol}, 1$ equiv.) in DCM (1 mL) at room temperature. The reaction mixture was stirred for $10 \mathrm{~min}$.

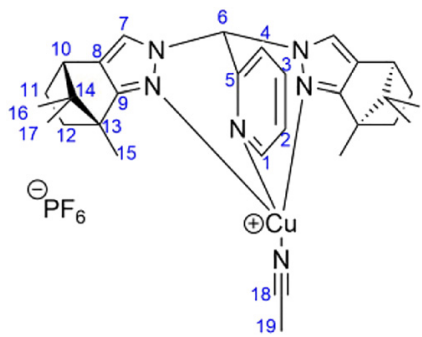


Chemical formula: $\mathrm{C}_{30} \mathrm{H}_{38} \mathrm{CuF}_{6} \mathrm{~N}_{6} \mathrm{P}$. Molecular mass: $691.19 \mathrm{~g} \mathrm{~mol}^{-1}-{ }^{1} \mathrm{H} \mathrm{NMR}\left(\mathrm{CD}_{2} \mathrm{Cl}_{2}, 400 \mathrm{MHz}\right): \delta=8.61\left(\mathrm{~d},{ }^{3} \mathrm{~J}=4.8 \mathrm{~Hz}, 1 \mathrm{H}\right.$, $\mathrm{H}-1), 7.89\left(\mathrm{td},{ }^{3} \mathrm{~J}=7.8 \mathrm{~Hz},{ }^{4} \mathrm{~J}=1.6 \mathrm{~Hz}, 1 \mathrm{H}, \mathrm{H}-3\right), 7.82\left(\mathrm{~d},{ }^{3} \mathrm{~J}=7.8 \mathrm{~Hz}, 1 \mathrm{H}, \mathrm{H}-4\right)$, 7.44 (m, 3H, H2+H-7), 7.36 (s, $1 \mathrm{H}, \mathrm{H}-6$ ), 2.75 (t, ${ }^{3} \mathrm{~J}=4.3 \mathrm{~Hz}, 2 \mathrm{H}, \mathrm{H}-10$ ), 2.01 (m, 5H, H-11+H-19), 1.82 (m, 2H, H-12), 1.30 (2× s, 6H, H-15), 1.21-1.00 (m, 4H, H-11 + H-12), 0.91 (2× s, 6H, H-16/17), 0.48 (2× s, 6H, H-16/17) ppm ${ }^{13} \mathrm{C}\left\{{ }^{1} \mathrm{H}\right\}$ NMR $\left(\mathrm{CD}_{2} \mathrm{Cl}_{2}, 100 \mathrm{MHz}\right): \delta=167.2$ (d, C-9), 152.1 (C-5), $148.2(\mathrm{C}-1)$, 138.3 (C-3), 126.6 (d, C-8), 124.0 (C-2), 123.6 (C-4), 122.9 (d, C-7), 115.6 (C-18), 71.2 (C-6), 59.9 (C-13), 50.0 (C-14), 46.3 (C-10), 32.3 (d, C-12), 26.3 (d, C-11), 19.1 (d, C-16/17), 17.7 (d, C-16/17), 9.3 (d, C-15), 0.9 (C-19) ppm. Note: The doublets are due to the asymmetry of the pyrazolyl units, therefore no J couplings are given. $-{ }^{19} \mathrm{~F}\left\{{ }^{1} \mathrm{H}\right\}$ NMR $\left(\mathrm{CD}_{2} \mathrm{Cl}_{2}, 377 \mathrm{MHz}\right): \delta=-72.1$ $(\mathrm{d}, J=711 \mathrm{~Hz}) \mathrm{ppm}-{ }^{31} \mathrm{P}\left\{{ }^{1} \mathrm{H}\right\}$ NMR $\left(\mathrm{CD}_{2} \mathrm{Cl}_{2}, 162 \mathrm{MHz}\right): \delta=-144.1$ (sept, $J=711 \mathrm{~Hz}) \mathrm{ppm}$. Note: As mentioned above the NMR spectra have to be recorded in the presence of acetonitrile. - HRMS ((+)-ESI, MeOH): $m / z$ (found): 545.24506 (100\%), 546.24791 (37\%), 547.24364 (52\%), 548.24629 (17\%), 549.24915 (3\%); $m / z$ (calc.): $545.24539\left(100 \%,{ }^{12} \mathrm{C}_{30}{ }^{1} \mathrm{H}_{38}{ }^{63} \mathrm{Cu}_{1}{ }^{14} \mathrm{~N}_{6}{ }^{+}\right)$, $546.24875 \quad\left(32 \%,{ }^{13} \mathrm{C}_{1}{ }^{12} \mathrm{C}_{29}{ }^{1} \mathrm{H}_{38}{ }^{63} \mathrm{Cu}_{1}{ }^{14} \mathrm{~N}_{6}{ }^{+}\right), \quad 547.24358 \quad\left(45 \%,{ }^{12} \mathrm{C}_{30}{ }^{1} \mathrm{H}_{38}\right.$ $\left.{ }^{65} \mathrm{Cu}_{1}{ }^{14} \mathrm{~N}_{6}{ }^{+}\right), 548.24694\left(14 \%,{ }^{13} \mathrm{C}_{1}{ }^{12} \mathrm{C}_{29}{ }^{1} \mathrm{H}_{38}{ }^{65} \mathrm{Cu}_{1}{ }^{14} \mathrm{~N}_{6}{ }^{+}\right), 549.25029(2 \%$, ${ }^{13} \mathrm{C}_{2}{ }^{12} \mathrm{C}_{28}{ }^{1} \mathrm{H}_{38}{ }^{65} \mathrm{Cu}_{1}{ }^{14} \mathrm{~N}_{6}{ }^{+}$). - IR (ATR, neat), $\tilde{v}\left(\mathrm{~cm}^{-1}\right): 3127$ (vw), 2965 (w), 2872 (vw), 1599 (w), 1392 (w), 1343 (vw), 1278 (w), 1241 (vw), 1179 (vw), $1141(\mathrm{w}), 1088(\mathrm{vw}), 1008(\mathrm{w}), 981(\mathrm{vw}), 878(\mathrm{w}), 838(\mathrm{vs}), 786(\mathrm{w}), 770(\mathrm{w})$, $740(\mathrm{w}), 691(\mathrm{w}), 674(\mathrm{w}), 630(\mathrm{vw}), 613(\mathrm{vw}), 603(\mathrm{vw}), 557(\mathrm{~s})$.

Additional information on the NMR of the target compound including original data files is available via Chemotion Repository:

https://dx.doi.org/10.14272/FZZQSTGFSCTJEY-QGLSCBPMSAN.1

4.2.6 Synthesis of $\left[\mathrm{Cu}\left\{\mathrm{HC}\left({ }^{t} \mathrm{BuPz}\right)_{2}\left(6-\mathrm{CO}_{2} \mathrm{MePy}\right)\right\}(\mathrm{MeCN})\right] \mathrm{PF}_{6}$ (C3): A solution of $\mathrm{HC}\left({ }^{t} \mathrm{BuPz}\right)_{2}\left(6-\mathrm{CO}_{2} \mathrm{MePy}\right)(159.2 \mathrm{mg}, 0.40 \mathrm{mmol}, 1$ equiv. $)$ in acetone $(5 \mathrm{~mL})$ was added dropwise to a solution of $\left[\mathrm{Cu}(\mathrm{MeCN})_{4}\right] \mathrm{PF}_{6}$ (150.0 mg, $0.40 \mathrm{mmol}, 1$ equiv.) in acetone $(10 \mathrm{~mL})$. The solution was stirred at room temperature overnight. The complex was crystallized by layering the solution with pentane for a few days. The product was filtered, washed with acetone/pentane $(1 / 2,3 \times 1 \mathrm{~mL})$ and dried in vacuo to yield the complex $\left[\mathrm{Cu}\left\{\mathrm{HC}\left({ }^{t} \mathrm{BuPz}\right)_{2}\left(6-\mathrm{CO}_{2} \mathrm{MePy}\right)\right\}(\mathrm{MeCN})\right] \mathrm{PF}_{6}$ (215 mg, $0.33 \mathrm{mmol}, 82 \%$ ).

Crystals suitable for single-crystal X-ray diffraction were obtained from a concentrated solution of $\left[\mathrm{Cu}\left\{\mathrm{HC}\left({ }^{t} \mathrm{BuPz}\right)_{2}\left(6-\mathrm{CO}_{2} \mathrm{MePy}\right)\right\}(\mathrm{MeCN})\right]$ $\mathrm{PF}_{6}$ in DCM, which was layered with $n$-hexane.

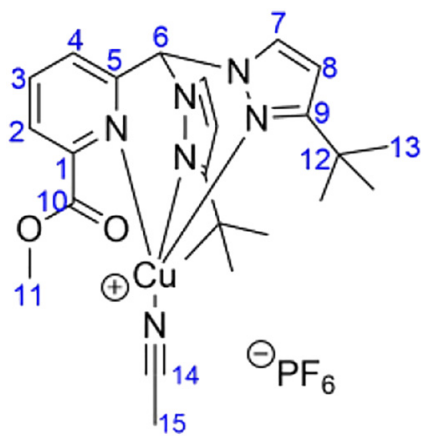

Chemical formula: $\mathrm{C}_{24} \mathrm{H}_{32} \mathrm{CuF}_{6} \mathrm{~N}_{6} \mathrm{O}_{2} \mathrm{P}$. Molecular mass: 645.07 $\mathrm{g} \mathrm{mol}^{-1}-{ }^{1} \mathrm{H} \mathrm{NMR}\left(\mathrm{CD}_{2} \mathrm{Cl}_{2}, 400 \mathrm{MHz}\right): \delta=8.16(\mathrm{~m}, 2 \mathrm{H}, \mathrm{H}-3, \mathrm{H}-4), 8.01$ $\left(\mathrm{d},{ }^{3} \mathrm{~J}=2.6 \mathrm{~Hz}, 2 \mathrm{H}, \mathrm{H}-7\right), 7.91$ (d, $\left.{ }^{3} \mathrm{~J}=7.3 \mathrm{~Hz}, 1 \mathrm{H}, \mathrm{H}-2\right), 7.85$ (s, $1 \mathrm{H}, \mathrm{H}-6$ ), 6.27 (d, ${ }^{3} \mathrm{~J}=2.6 \mathrm{~Hz}, 2 \mathrm{H}, \mathrm{H}-8$ ), 4.03 (s, 3H, H-11), 2.31 (s, 3H, H-15), 1.39 (s, 18H, H-13) ppm $-{ }^{13} \mathrm{C}\left\{{ }^{1} \mathrm{H}\right\}$ NMR $\left(\mathrm{CD}_{2} \mathrm{Cl}_{2}, 100 \mathrm{MHz}\right): \delta=165.5$ (C-10), 165.2 (C-9), 153.4 (C-5), 147.9 (C-3), 141.4 (C-1), 133.5 (C-7), 128.8 (C-2),
127.0 (C-4), 117.1 (C-14), 104.6 (C-8), 73.2 (C-6), 54.2 (C-11), 32.7 (C-12), 30.5 (C-13), $3.1(\mathrm{C}-15) \mathrm{ppm}-{ }^{19} \mathrm{~F}\left\{{ }^{1} \mathrm{H}\right\}$ NMR $\left(\mathrm{CD}_{2} \mathrm{Cl}_{2}, 377 \mathrm{MHz}\right): \delta=-71.9$ (d, $J=711 \mathrm{~Hz}) \mathrm{ppm}-{ }^{31} \mathrm{P}\left\{{ }^{1} \mathrm{H}\right\} \mathrm{NMR}\left(\mathrm{CD}_{2} \mathrm{Cl}_{2}, 162 \mathrm{MHz}\right): \delta=-144.2$ (sept, $J=711 \mathrm{~Hz}) \mathrm{ppm}-$ HRMS ((+)-ESI, MeOH): $m / z$ (found): 458.16077 (100\%), 459.16364 (24\%), 460.15900 (48\%), 461.16190 (10\%), 462.16489 (1\%); $m / z$ (calc.): $458.16172\left(100 \%,{ }^{12} \mathrm{C}_{22}{ }^{1} \mathrm{H}_{29}{ }^{63} \mathrm{Cu}_{1}{ }^{14} \mathrm{~N}_{5}{ }^{16} \mathrm{O}_{2}{ }^{+}\right), 459.16508$ (24\%, $\left.\quad{ }^{12} \mathrm{C}_{21}{ }^{13} \mathrm{C}_{1}^{1} \mathrm{H}_{29}{ }^{63} \mathrm{Cu}_{1}{ }^{14} \mathrm{~N}_{5}{ }^{16} \mathrm{O}_{2}{ }^{+}\right), \quad 460.15991 \quad\left(45 \%, \quad{ }^{12} \mathrm{C}_{22}{ }^{1} \mathrm{H}_{29}\right.$ $\left.{ }^{65} \mathrm{Cu}_{1}{ }^{14} \mathrm{~N}_{5}{ }^{16} \mathrm{O}_{2}{ }^{+}\right), 461.16327\left(11 \%,{ }^{12} \mathrm{C}_{21}{ }^{13} \mathrm{C}_{1}{ }^{1} \mathrm{H}_{29}{ }^{65} \mathrm{Cu}_{1}{ }^{14} \mathrm{~N}_{5}{ }^{16} \mathrm{O}_{2}{ }^{+}\right), 462.16662$ (1\%, ${ }^{12} \mathrm{C}_{20}{ }^{13} \mathrm{C}_{2}^{1} \mathrm{H}_{29}{ }^{65} \mathrm{Cu}_{1}{ }^{14} \mathrm{~N}_{5}{ }^{16} \mathrm{O}_{2}{ }^{+}$). - IR (ATR, neat), $\tilde{v}\left(\mathrm{~cm}^{-1}\right): 3154$ (vw), 2966 (w), 2873 (vw), 1734 (w), 1595 (vw), 1576 (vw), 1521 (w), 1485 (vw), 1462 (w), 1434 (w), 1415 (vw), 1363 (w), 1321 (w), 1288 (vw), 1236 (m), 1202 (w), 1173 (w), 1143 (w), 1064 (w), 1012 (vw), 930 (vw), 876 (w), $832(\mathrm{vs}), 800(\mathrm{~m}), 772(\mathrm{~m}), 760(\mathrm{~s}), 740(\mathrm{w}), 726(\mathrm{~m}), 702(\mathrm{~m}), 654(\mathrm{~m})$, $556(\mathrm{~s}), 498(\mathrm{vw})$.

Additional information on the NMR of the target compound including original data files is available via Chemotion Repository:

https://dx.doi.org/10.14272/UQZCBWVOIVXJNI-UHFFFAOYSAN.1

4.2.7 Synthesis of $\left[\mathrm{Cu}_{2}\left[\mathrm{HC}(\mathrm{CamPz})_{2} \mathrm{Py}_{2}\right]\left(\mathrm{PF}_{6}\right)_{2}\right.$ (C4): A solution of $\mathrm{HC}(\mathrm{CamPz})_{2} \mathrm{Py}(22.1 \mathrm{mg}, 0.05 \mathrm{mmol}, 1$ equiv.) in acetone $(0.5 \mathrm{~mL})$ was added to solution of $\left[\mathrm{Cu}(\mathrm{MeCN})_{4}\right] \mathrm{PF}_{6}(18.6 \mathrm{mg}, 0.05 \mathrm{mmol}, 1$ equiv.) in acetone $(0.5 \mathrm{~mL})$. The solution was stirred overnight. Hexane $(4 \mathrm{~mL})$ was added and a precipitate formed, which was collected by filtration and washed with hexane to yield $\left[\mathrm{Cu}_{2}\left\{\mathrm{HC}(\mathrm{CamPz})_{2} \mathrm{Py}\right\}_{2}\right]\left(\mathrm{PF}_{6}\right)_{2}(26.3 \mathrm{mg}$, $0.02 \mathrm{mmol}, 80 \%)$.

The reaction can also be performed with DCM and THF as solvent.

Crystals suitable for single crystal $\mathrm{X}$-ray diffraction were obtained from a concentrated solution of $\left[\mathrm{Cu}_{2}\left\{\mathrm{HC}(\mathrm{CamPz})_{2} \mathrm{Py}_{2}\right]\left(\mathrm{PF}_{6}\right)_{2}\right.$ in DCM, which was layered with $n$-hexane.

A high concentration is beneficial to avoid the formation of a $[\mathrm{Cu} \mathbf{L}(\mathrm{MeCN})] P F_{6}$ coordination motif, which may occur as an impurity.

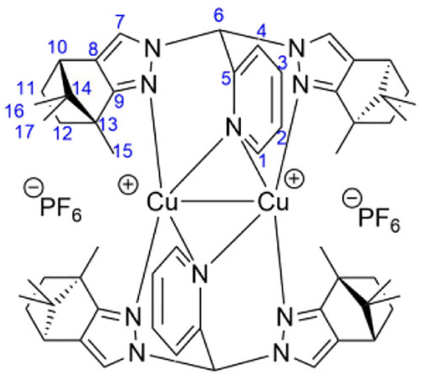

Chemical formula: $\mathrm{C}_{56} \mathrm{H}_{70} \mathrm{Cu}_{2} \mathrm{~F}_{12} \mathrm{~N}_{10} \mathrm{P}_{2}$. Molecular mass: 1300.27 $\mathrm{g} \mathrm{mol}^{-1}-{ }^{1} \mathrm{H}$ NMR $\left(\mathrm{CD}_{2} \mathrm{Cl}_{2}, 400 \mathrm{MHz}\right): \delta=8.22\left(\mathrm{~d},{ }^{3} \mathrm{~J}=7.6 \mathrm{~Hz}, 2 \mathrm{H}, \mathrm{H}-1\right), 8.14$ $\left(\mathrm{td},{ }^{3} \mathrm{~J}=8.1 \mathrm{~Hz},{ }^{4} \mathrm{~J}=1.5 \mathrm{~Hz}, 2 \mathrm{H}, \mathrm{H}-2\right), 8.07$ (s, 2H, H-6), 8.01 (s, 2H, H-7), 7.95 (s, 2H, H-7), $7.65\left(\mathrm{dd},{ }^{3} \mathrm{~J}=5.1 \mathrm{~Hz},{ }^{4} \mathrm{~J}=1.5 \mathrm{~Hz}, 2 \mathrm{H}, \mathrm{H}-4\right), 7.42\left(\mathrm{t},{ }^{3} \mathrm{~J}=6.2 \mathrm{~Hz}, 2 \mathrm{H}\right.$, $\mathrm{H}-3$ ), 2.92 (m, 4H, H-10), 2.09 (m, 4H, H-11), 1.73 (m, 4H, H-12), 1.20 (m, 4H, $\mathrm{H}-11), 1.03$ (m, 4H, H-12), 0.87 (s, 6H, H-16/17), 0.85 (s, 6H, H-16/17), 0.62 (s, 6H, H-16/17), 0.55 (s, 6H, H-15), 0.53 (s, 6H, H-15), 0.50 (s, 6H, H-16/17) ppm $-{ }^{13} \mathrm{C}\left\{{ }^{1} \mathrm{H}\right\}$ NMR $\left(\mathrm{CD}_{2} \mathrm{Cl}_{2}, 100 \mathrm{MHz}\right): \delta=171.3$ (C-9), 170.2 (C-9), 151.4 (C-5), 150.6 (C-4), 142.0 (C-2), 129.8 (d, C-8), 129.1 (C-1), 128.1 (d, C-7), 126.9 (C-3), 73.0 (C-6), 62.7 (C-14), 61.4 (C-14), 51.9 (d, C-13), 47.6 (d, C-10), 34.0 (d, C-12), 27.3 (d, C-11), 20.9 (d, C-16/17), 18.9 (d, C-16/17), 10.9 (d, C-15) $\mathrm{ppm}$. Note: The doublets are due to the asymmetry of the pyrazolyl units, therefore no J couplings are given. $-{ }^{19} \mathrm{~F}\left\{{ }^{1} \mathrm{H}\right\} \mathrm{NMR}\left(\mathrm{CD}_{2} \mathrm{Cl}_{2}, 377 \mathrm{MHz}\right)$ : $\delta=-71.3(\mathrm{~d}, J=711 \mathrm{~Hz}) \mathrm{ppm}-{ }^{31} \mathrm{P}\left\{{ }^{1} \mathrm{H}\right\} \mathrm{NMR}\left(\mathrm{CD}_{2} \mathrm{Cl}_{2}, 162 \mathrm{MHz}\right): \delta=-143.9$ (sept, $J=711 \mathrm{~Hz}$ ) ppm - HRMS ((+)-ESI, MeOH): $m / z$ (found): 1153.40076 (98\%), 1154.40427 (60\%), 1155.40034 (100\%), 1156.40307 (55\%), 
1157.40151 (30\%), 1158.40221 (13\%), 1159.40505 (4\%); $\mathrm{m} / z$ (calc.): $1153.40187\left(100 \%,{ }^{12} \mathrm{C}_{56} \mathrm{H}_{70}{ }^{63} \mathrm{Cu}_{2}{ }^{14} \mathrm{~N}_{10}{ }^{31} \mathrm{P}_{1}{ }^{19} \mathrm{~F}_{6}{ }^{+}\right), 1154.40522\left(61 \%,{ }^{13} \mathrm{C}_{1}{ }^{12} \mathrm{C}_{55}\right.$ $\left.{ }^{1} \mathrm{H}_{70}{ }^{63} \mathrm{Cu}_{2}{ }^{14} \mathrm{~N}_{10}{ }^{31} \mathrm{P}_{1}{ }^{19} \mathrm{~F}_{6}{ }^{+}\right), 1155.40006\left(89 \%,{ }^{12} \mathrm{C}_{56}{ }^{1} \mathrm{H}_{70}{ }^{65} \mathrm{Cu}_{1}{ }^{63} \mathrm{Cu}_{1}{ }^{14} \mathrm{~N}_{10}{ }^{31} \mathrm{P}_{1}\right.$ $\left.{ }^{19} \mathrm{~F}_{6}{ }^{+}\right), 1156.40341\left(54 \%,{ }^{13} \mathrm{C}_{1}{ }^{12} \mathrm{C}_{55}{ }^{1} \mathrm{H}_{70}{ }^{65} \mathrm{Cu}_{1}{ }^{63} \mathrm{Cu}_{1}{ }^{14} \mathrm{~N}_{10}{ }^{31} \mathrm{P}_{1}{ }^{19} \mathrm{~F}_{6}{ }^{+}\right), 1157.40110$ (27\%, $\left.{ }^{12} \mathrm{C}_{56}{ }^{1} \mathrm{H}_{70}{ }^{65} \mathrm{Cu}_{2}{ }^{14} \mathrm{~N}_{10}{ }^{31} \mathrm{P}_{1}^{19} \mathrm{~F}_{6}{ }^{+},{ }^{13} \mathrm{C}_{2}^{12} \mathrm{C}_{54}{ }^{1} \mathrm{H}_{70}{ }^{65} \mathrm{Cu}_{1}{ }^{63} \mathrm{Cu}_{1}{ }^{14} \mathrm{~N}_{10}{ }^{31} \mathrm{P}_{1}{ }^{19} \mathrm{~F}_{6}{ }^{+}\right)$, $1158.40161 \quad\left(12 \%,{ }^{13} \mathrm{C}_{1}^{12} \mathrm{C}_{55}{ }^{1} \mathrm{H}_{70}{ }^{65} \mathrm{Cu}_{2}{ }^{14} \mathrm{~N}_{10}{ }^{31} \mathrm{P}_{1}{ }^{19} \mathrm{~F}_{6}{ }^{+}\right), \quad 1159.40496 \quad(4 \%$, $\left.{ }^{13} \mathrm{C}_{2}{ }^{12} \mathrm{C}_{54}{ }^{1} \mathrm{H}_{70}{ }^{65} \mathrm{Cu}_{2}{ }^{14} \mathrm{~N}_{10}{ }^{31} \mathrm{P}_{1}^{19} \mathrm{~F}_{6}{ }^{+}\right), 1160.40831\left(1 \%,{ }^{13} \mathrm{C}_{3}{ }^{12} \mathrm{C}_{53}{ }^{1} \mathrm{H}_{70}{ }^{65} \mathrm{Cu}_{2}{ }^{14} \mathrm{~N}_{10}\right.$ ${ }^{31} \mathrm{P}_{1}^{19} \mathrm{~F}_{6}^{+}$). - IR (ATR, neat), $\tilde{v}\left(\mathrm{~cm}^{-1}\right): 3127(\mathrm{vw}), 2962(\mathrm{w}), 2918$ (vw), 2872 (vw), 1598 (w), 1392 (w), 1343 (w), 1276 (w), 1267 (w), 1242 (vw), 1210 (w), 1176 (w), 1140 (w), 1007 (w), 984 (vw), 835 (vs), 786 (w), 772 (m), 739 (w), 691 (w), 674 (w), 631 (w), 615 (vw), 604 (vw), 556 (s).

Additional information on the NMR of the target compound including original data files is available via Chemotion Repository: https://dx.doi.org/10.14272/FHXONRJROWMHDX-QUJLYIJBSAN.1

\subsection{Catalytic reactions}

\subsubsection{Aziridination of styrene derivatives}

4.3.1.1 Aziridination with isolated catalyst: Styrene derivative $\left(8.73 \times 10^{-5} \mathrm{~mol}, 1\right.$ equiv. $)$ and DCM $(0.5 \mathrm{~mL})$ were added to the catalyst ( $5 \times 10^{-6} \mathrm{~mol}, 0.05$ equiv.), PhINTs $\left(38.6 \mathrm{mg}, 1.0 \times 10^{-4} \mathrm{~mol}, 1.15\right.$ equiv. $)$ and molecular sieve ( $3 \AA$ Å). The reaction mixture was stirred for $24 \mathrm{~h}$ at room temperature. The solvent and remaining substrate were removed in vacuo. The residue was dissolved in $\mathrm{CDCl}_{3} / \mathrm{MeNO}_{2}(1 \mathrm{~mL}, 10 \mathrm{~mL} /$ $20 \mu \mathrm{L}$ ) and filtered. The yield was determined by ${ }^{1} \mathrm{H}$ NMR spectroscopy.

4.3.1.2 Aziridination with in situ prepared catalyst: Styrene derivative $\left(8.73 \times 10^{-5} \mathrm{~mol}, 1\right.$ equiv.), DCM $(0.4 \mathrm{~mL})$ and a solution of $\mathbf{C 4}$ $\left(2.5 \times 10^{-6}\right.$ mol, 0.025 equiv.) in $\mathrm{MeCN}\left(5.0 \times 10^{-5} \mathrm{~mol}, 0.5\right.$ equiv $)$ and DCM $(0.1 \mathrm{~mL})$ were added to PhINTs $\left(38.6 \mathrm{mg}, 1.0 \times 10^{-4} \mathrm{~mol}\right.$, 1.15 equiv.) and molecular sieve ( $3 \AA$ A $)$. The reaction mixture was stirred for $24 \mathrm{~h}$ at room temperature. The solvent and remaining substrate were removed in vacuo. The residue was dissolved in $\mathrm{CDCl}_{3} / \mathrm{MeNO}_{2}$ $(1 \mathrm{~mL}, 10 \mathrm{~mL} / 20 \mu \mathrm{L})$ and filtered. The yield was determined by ${ }^{1} \mathrm{H} \mathrm{NMR}$ spectroscopy.

\subsection{2 $\mathrm{C}-\mathrm{H}$ amination of benzylic and aliphatic substrates}

4.3.2.1 $\mathbf{C}-\boldsymbol{H}$ amination with isolated catalyst: Toluene $(1 \mathrm{~mL}$, $9.40 \times 10^{-3} \mathrm{~mol}$, 188 equiv.) or ethylbenzene $\left(1 \mathrm{~mL}, 8.19 \times 10^{-3} \mathrm{~mol}, 164\right.$ equiv.) and chlorobenzene $(1 \mathrm{~mL})$ were added to the catalyst $\left(5.00 \times 10^{-6} \mathrm{~mol}, 0.1\right.$ equiv.), ${ }^{S}$ PhINTs $\left(24.7 \mathrm{mg}, 5.00 \times 10^{-5} \mathrm{~mol}, 1\right.$ equiv. $)$ and molecular sieve ( $3 \AA$ ). The reaction mixture was stirred for $24 \mathrm{~h}$ at room temperature. The solvent and remaining substrate were removed in vacuo. The residue was dissolved in $\mathrm{CDCl}_{3} / \mathrm{MeNO}_{2}(1 \mathrm{~mL}, 10 \mathrm{~mL} / 20 \mu \mathrm{L})$ and filtered. The yield was determined by ${ }^{1} \mathrm{H}$ NMR spectroscopy.

Cyclohexane ( $0.3 \mathrm{~mL}, 2.8 \times 10^{-3} \mathrm{~mol}, 28$ equiv.) and chlorobenzene $(0.3 \mathrm{~mL})$ were added to the catalyst $\left(1.00 \times 10^{-5} \mathrm{~mol}, 0.1\right.$ equiv. $)$, ${ }^{\mathrm{S}}$ PhINTs (49.4 mg, $1.00 \times 10^{-4} \mathrm{~mol}, 1$ equiv.) and molecular sieve (3 $\AA$ ). The reaction mixture was stirred for $48 \mathrm{~h}$ at room temperature. The solvent and remaining substrate were removed in vacuo. The residue was dissolved in $\mathrm{CDCl}_{3} / \mathrm{MeNO}_{2}(1 \mathrm{~mL}, 10 \mathrm{~mL} / 20 \mu \mathrm{L})$ and filtered. The yield was determined by ${ }^{1} \mathrm{H}$ NMR spectroscopy.

4.3.2.2 C-H amination with in situ prepared catalyst: One of the three substrates (see Section 4.3.2.1), DCM $(0.9 \mathrm{~mL})$ and a solution of $\mathbf{C 4}$ $\left(2.5 \times 10^{-6} \mathrm{~mol}, 0.05\right.$ equiv. $)$ in $\mathrm{MeCN}\left(5.0 \times 10^{-5} \mathrm{~mol}, 0.1\right.$ equiv) and DCM $(0.1 \mathrm{~mL})$ were added to ${ }^{5}$ PhINTs $\left(24.7 \mathrm{mg}, 5.00 \times 10^{-5} \mathrm{~mol}\right.$, 1 equiv.) and molecular sieve ( $3 \AA$ ). The reaction mixtures were stirred for $24 \mathrm{~h}$ at room temperature. The solvent and remaining substrate were removed in vacuo. The residues were dissolved in $\mathrm{CDCl}_{3} / \mathrm{MeNO}_{2}$ $(1 \mathrm{~mL}, 10 \mathrm{~mL} / 20 \mu \mathrm{L})$ and filtered. The yields were determined by ${ }^{1} \mathrm{H}$ NMR spectroscopy.

\section{Supporting information}

The experimental and simulated EPR spectra of $\mathbf{N 1 P F}_{\mathbf{6}}$ and $\mathbf{N} \mathbf{P F}_{\mathbf{6}}$, the UV/Vis spectra of the UV/Vis experiments of $\mathbf{N 1 P F}_{\mathbf{6}}$ and $\mathbf{N} \mathbf{2} \mathbf{P F}_{\mathbf{6}}$, the mass spectra of the decay species of $\mathbf{N} 2 \mathbf{P F}_{\mathbf{6}}$, an overview over all catalytic reactions, the CV data of C1-C4, all NMR spectra and an overview over the crystallographic data are given as supplementary material available online (https://doi.org/10.1515/znb-2021-0140).

Author contributions: All the authors have accepted responsibility for the entire content of this submitted manuscript and approved submission.

Research funding: Financial support by the Deutsche Forschungsgemeinschaft in the framework of the SFB 985 (Subproject A1) is gratefully acknowledged.

Conflict of interest statement: The authors declare no conflicts of interest regarding this article.

\section{References}

1. Collet F., Dodd R. H., Dauban P. Chem. Commun. 2009, 5061-5074; https://doi.org/10.1039/b905820f.

2. Hili R., Yudin A. K. Nat. Chem. Biol. 2006, 2, 284-287.

3. Roughley S. D., Jordan A. M. J. Med. Chem. 2011, 54, 3451-3479.

4. Abdine R. A. A., Hedouin G., Colobert F., Wencel-Delord J. ACS Catal. 2021, 11, 215-247.

5. Sutin L., Andersson S., Bergquist L., Castro V. M., Danielsson E., James S., Henriksson M., Johansson L., Kaiser C., Flyrén K., Williams M. Bioorg. Med. Chem. Lett 2007, 4837-4840; https://doi.org/10.1016/j.bmcl.2007.06.054.

6. Bergman R. G. Nature 2007, 446, 391-393.

7. Davies H. M. L., Morton D. J. Org. Chem. 2016, 81, 343-350.

8. Tzouras N. V., Stamatopoulos I. K., Papastavrou A. T., Liori A. A., Vougioukalakis G. C. Coord. Chem. Rev. 2017, 343, 25-138.

9. Hartwig J. F. Nature 2008, 455, 314-322.

10. Davies H. M. L., Manning J. R. Nature 2008, 451, 417-424.

11. Roizen J. L., Harvey M. E., Du Bois J. Acc. Chem. Res. 2012, 45, 911-922.

12. Iovan D. A., Betley T. A. J. Am. Chem. Soc. 2016, 138, 1983-1993.

13. Kuijpers P. F., van der Vlugt J. I., Schneider S., Bruin B. Chem. Eur. J. 2017, 23, 13819-13829.

14. Scamp R. J., Scheffer B., Schomaker J. M. Chem. Commun. 2019, 55, 7362-7365.

15. Rey-Rodriguez R., Grelier G., Habert L., Retailleau P., Darses B., Gillaizeau I., Dauban P. J. Org. Chem. 2017, 82, 11897-11902.

16. Dequirez G., Pons V., Dauban P. Angew. Chem. Int. Ed. 2012, 51, 7384-7395. 
17. Bagchi V., Paraskevopoulou P., Das P., Chi L., Wang Q., Choudhury A., Mathieson J. S., Cronin L., Pardue D. B., Cundari T. R., Mitrikas G., Sanakis Y., Stavropoulos P. J. Am. Chem. Soc. 2014, 136, 11362-11381.

18. Barman D. N., Nicholas K. M. Tetrahedron Lett. 2010, 51, 1815-1818.

19. Bhuyan R., Nicholas K. M. Org. Lett. 2007, 9, 3957-3959.

20. Díaz-Requejo M. M., Belderraín T. R., Nicasio M. C., Trofimenko S., Pérez P. J. J. Am. Chem. Soc. 2003, 125, 12078-12079.

21. Fructos M. R., Trofimenko S., Díaz-Requejo M. M., Pérez P. J. J. Am. Chem. Soc. 2006, 128, 11784-11791.

22. Gephart R. T., Warren T. H. Organometallics 2012, 31, 7728-7752.

23. Vedernikov A. N., Caulton K. G. Chem. Commun. 2004, 162-163; https://doi.org/10.1039/b309519c.

24. Bakhoda A. G., Jiang Q., Badiei Y. M., Bertke J. A., Cundari T. R., Warren T. H. Angew. Chem. Int. Ed. 2019, 58, 3421-3425.

25. Amisial L. D., Dai X., Kinney R. A., Krishnaswamy A., Warren T. H. Inorg. Chem. 2004, 43, 6537-6539.

26. Ando T., Minakata S., Ryu I., Komatsu M. Tetrahedron Lett. 1998, 39, 309-312.

27. Arenas I., Fuentes M. Á., Alvarez E., Díaz Y., Caballero A., Castillón S., Pérez P. J. Inorg. Chem. 2014, 53, 3991-3999.

28. Chanda B. M., Vyas R., Bedekar A. V. J. Org. Chem. 2001, 66, 30-34.

29. Comba P., Haaf C., Lienke A., Muruganantham A., Wadepohl H. Chem. Eur J. 2009, 15, 10880-10887.

30. Comba P., Merz M., Pritzkow H. Eur. J. Inorg. Chem. 2003, 2003, 1711-1718.

31. Evans D. A., Bilodeau M. T., Faul M. M. J. Am. Chem. Soc. 1994, 116, 2742-2753.

32. Gillespie K. M., Crust E. J., Deeth R. J., Scott P. Chem. Commun. 2001, 785-786; https://doi.org/10.1039/b101415n.

33. Haldón E., Delgado-Rebollo M., Prieto A., Alvarez E., Maya C., Nicasio M. C., Pérez P. J. Inorg. Chem. 2014, 53, 4192-4201.

34. Nebra N., Lescot C., Dauban P., Mallet-Ladeira S., Martin-Vaca B., Bourissou D. Eur. J. Org. Chem. 2013, 2013, 984-990.

35. Vedernikov A. N., Caulton K. G. Org. Lett. 2003, 5, 2591-2594.

36. Wu H., Xu L.-W., Xia C.-G., Ge J., Zhou W., Yang L. Catal. Commun. 2005, 6, 221-223.

37. Comba P., Lang C., Lopez de Laorden C., Muruganantham A., Rajaraman G., Wadepohl H., Zajaczkowski M. Chem. Eur J. 2008, 14, 5313-5328.

38. van Vliet K. M., Polak L. H., Siegler M. A., van der Vlugt J. I., Guerra C. F., de Bruin B. J. Am. Chem. Soc. 2019, 141, 15240-15249.

39. Evans D. A., Faul M. M., Bilodeau M. T., Anderson B. A., Barnes D. M. J. Am. Chem. Soc. 1993, 115, 5328-5329.

40. Gullick J., Taylor S., McMorn P., Bethell D., Bulman Page P. C., Hancock F. E., King F., Hutchings G. J. Mol. Catal. Chem. 2002, 180, 85-89.

41. Taylor S., Gullick J., McMorn P., Bethell D., Bulman Page P. C., Hancock F. E., King F., Hutchings G. J. J. Chem. Soc Perkin Trans. 2001, 2, 1714-1723.

42. Li Z., Conser K. R., Jacobsen E. N. J. Am. Chem. Soc. 1993, 115, 5326-5327.

43. Li Z., Quan R. W., Jacobsen E. N. J. Am. Chem. Soc. 1995, 117, 5889-5890.

44. Wang X., Ding K. Chem. Eur J. 2006, 12, 4568-4575.

45. Kwong H.-L., Liu D., Chan K.-Y., Lee C.-S., Huang K.-H., Che C.-M. Tetrahedron Lett. 2004, 45, 3965-3968.
46. Kuijpers P. F., Tiekink M. J., Breukelaar W. B., Broere D. L. J., van Leest N. P., van der Vlugt J. I., Reek J. N. H., Bruin B. Chem. Eur. J. 2017, 23, 7945-7952.

47. Aguila M. J. B., Badiei Y. M., Warren T. H. J. Am. Chem. Soc. 2013, 135, 9399-9406.

48. Barman D. N., Liu P., Houk K. N., Nicholas K. M. Organometallics 2010, 29, 3404-3412.

49. Brandt P., Södergren M. J., Andersson P. G., Norrby P.-O. J. Am. Chem. Soc. 2000, 122, 8013-8020.

50. Cano I., Álvarez E., Nicasio M. C., Pérez P. J. J. Am. Chem. Soc. 2011, 133, 191-193.

51. Maestre L., Sameera W. M. C., Díaz-Requejo M. M., Maseras F., Pérez P. J. J. Am. Chem. Soc. 2013, 135, 1338-1348.

52. Tekarli S. M., Williams T. G., Cundari T. R. J. Chem. Theor. Comput. 2009, 5, 2959-2966.

53. Hou K., Hrovat D. A., Bao X. Chem. Commun. 2015, 51, 15414-15417.

54. Park Y., Kim Y., Chang S. Chem. Rev. 2017, 117, 9247-9301.

55. Badiei Y. M., Dinescu A., Dai X., Palomino R. M., Heinemann F. W., Cundari T. R., Warren T. H. Angew. Chem. Int. Ed. 2008, 47, 9961-9964.

56. Badiei Y. M., Krishnaswamy A., Melzer M. M., Warren T. H. J. Am. Chem. Soc. 2006, 128, 15056-15057.

57. Wiese S., Badiei Y. M., Gephart R. T., Mossin S., Varonka M. S., Melzer M. M., Meyer K., Cundari T. R., Warren T. H. Angew. Chem. Int. Ed. 2010, 49, 8850-8855.

58. Corona T., Ribas L., Rovira M., Farquhar E. R., Ribas X., Ray K., Company A. Angew. Chem. Int. Ed. 2016, 55, 14005-14008.

59. Kundu S., Miceli E., Farquhar E., Pfaff F. F., Kuhlmann U., Hildebrandt P., Braun B., Greco C., Ray K. J. Am. Chem. Soc. 2012, 134, 14710-14713.

60. Abram S.-L., Monte-Pérez I., Pfaff F. F., Farquhar E. R., Ray K. Chem. Commun. 2014, 50, 9852-9854.

61. Monte-Pérez I., Kundu S., Ray K. Z. Anorg. Allg. Chem. 2015, 641, 78-82.

62. Dielmann F., Back O., Henry-Ellinger M., Jerabek P., Frenking G., Bertrand G. Science 2012, 337, 1526-1528.

63. Carsch K. M., DiMucci I. M., Iovan D. A., Li A., Zheng S.-L., Titus C. J., Lee S. J., Irwin K. D., Nordlund D., Lancaster K. M., Betley T. A. Science 2019, 365, 1138-1143.

64. Moegling J., Hoffmann A., Thomas F., Orth N., Liebhäuser P., Herber U., Rampmaier R., Stanek J., Fink G., Ivanović-Burmazović I., Herres-Pawlis S. Angew. Chem. Int. Ed. 2018, 57, 9154-9159.

65. Thomas F., Oster M., Schön F., Göbgen K. C., Amarouch B., Steden D., Hoffmann A., Herres-Pawlis S. Dalton Trans. 2021, 50, 6444-6462.

66. Moegling J., Hoffmann A., Herres-Pawlis S. Synthesis 2016, 49 , 225-236.

67. Liebhäuser P., Keisers K., Hoffmann A., Schnappinger T., Sommer I., Thoma A., Wilfer C., Schoch R., Stührenberg K., Bauer M., Dürr M., Ivanović-Burmazović I., Herres-Pawlis S. Chem. Eur J. 2017, 23, 12171-12183.

68. Wilfer C., Liebhäuser P., Hoffmann A., Erdmann H., Grossmann O., Runtsch L., Paffenholz E., Schepper R., Dick R., Bauer M., Dürr M., Ivanović-Burmazović I., Herres-Pawlis S. Chem. EurJ. 2015, 21, 17639-17649.

69. Wilfer C., Liebhäuser P., Erdmann H., Hoffmann A., Herres-Pawlis S. Eur. J. Inorg. Chem. 2015, 2015, 494-502. 
70. Hoffmann A., Citek C., Binder S., Goos A., Rübhausen M., Troeppner O., Ivanović-Burmazović I., Wasinger E. C., Stack T. D. P., HerresPawlis S. Angew. Chem. Int. Ed. 2013, 52, 5398-5401.

71. Schäfer D., Fink F., Kleinschmidt D., Keisers K., Thomas F., Hoffmann A., Pich A., Herres-Pawlis S. Chem. Commun. 2020, 56 , 5601-5604.

72. Moegling J., Benischke A. D., Hammann J. M., Vepřek N. A., Zoller F., Rendenbach B., Hoffmann A., Sievers H., Schuster M., Knochel P., Herres-Pawlis S. Eur. J. Org Chem. 2015, 2015, 7475-7483.

73. Mertens M. A. S., Thomas F., Nöth M., Moegling J., El-Awaad I., Sauer D. F., Dhoke G. V., Xu W., Pich A., Herres-Pawlis S., Schwaneberg U. Eur. J. Org Chem. 2019, 2019, 6341-6346.

74. Elflein J., Platzmann F., Burzlaff N. Eur. J. Inorg. Chem. 2007, 2007, 5173-5176.

75. Godau T., Bleifuss S. M., Müller A. L., Roth T., Hoffmann S., Heinemann F. W., Burzlaff N. Dalton Trans. 2011, 6547-6554; https://doi.org/10.1039/c1dt10032g.

76. Godau T., Platzmann F., Heinemann F. W., Burzlaff N. Dalton Trans. 2009, 254-255; https://doi.org/10.1039/b819596j.

77. Hoffmann A., Flörke U., Schürmann M., Herres-Pawlis S. Eur. J. Org Chem. 2010, 2010, 4136-4144.

78. Yang L., Powell D. R., Houser R. P. Dalton Trans. 2007, 955-964; https://doi.org/10.1039/b617136b.

79. Hayashi H., Uchida T. Eur. J. Org. Chem. 2020, 2020, 909-916.

80. Murru S., Mokar B. D., Bista R., Harakat D., Le Bras J., Fronczek F., Nicholas K. M., Srivastava R. S. Org. Chem. Front. 2021, 8, 3228-3237.

81. Leonard J., Lygo B., Procter G. Praxis der organischen Chemie; Ein Handbuch, VCH: Weinheim, 1996.
82. LeCloux D. D., Tokar C. J., Osawa M., Houser R. P., Keyes M. C., Tolman W. B. Organometallics 1994, 13, 2855-2866.

83. Kubas G. J., Monzyk B., Crumbliss A. L. Inorg. Synth. 1990, 90-91.

84. Macikenas D., Skrzypczak-Jankun E., Protasiewicz J. D. J. Am. Chem. Soc. 2011, 133, 4151.

85. Yamada Y., Yamamoto T., Okawara M. Chem. Lett. 1975, 4, 361-362.

86. Tremouilhac P., Lin C.-L., Huang P.-C., Huang Y.-C., Nguyen A., Jung N., Bach F., Ulrich R., Neumair B., Streit A., Bräse S. Angew. Chem. Int. Ed. 2020, 59, 22771-22778.

87. Stoll S., Schweiger A. J. Magn. Reson. 2006, 178, 42-55.

88. SMART (version 5.631), SAINT (version 8.37A) and SADABS (version 2008/1); Bruker AXS Inc.: Madison, Wisconsin (USA), 2008.

89. XPREP (version 5.1); Bruker AXS Inc.: Madison, Wisconsin (USA), 1997.

90. Sheldrick G. M. Acta Crystallogr. 2008, A64, 112.

91. Sheldrick G. M. Acta Crystallogr. 2015, A71, 3-8.

92. Sheldrick G. M. Acta Crystallogr. 2015, C71, 3-8.

93. Hübschle C. B., Sheldrick G. M., Dittrich B. J. Appl. Crystallogr. 2011, 44, 1281-1284.

94. Spek A. L. PLATON, A Multipurpose Crystallographic Tool; Utrecht University: Utrecht (The Netherlands), 2008.

95. Spek A. L. Acta Crystallogr. 2015, C71, 9-18.

Supplementary Material: The online version of this article offers supplementary material (https://doi.org/10.1515/znb-2021-0140). 